\title{
O PROFETA, OS DISCÍPULOS E O “ENVIADO”: COMENTÁRIOS A VIRGÍLIO AFONSO DA SILVA
}

\section{THE PROPHET, THE DISCIPLES AND THE "SENT": COMMENTS TO VIRGÍLIO AFONSO DA SILVA}

Resumo: Em um artigo de 2008, um dos discípulos de Robert Alexy, Lorenzo Zucca pontificou Alexy como o "profeta do sopesamento estruturado". Essa rotulação panegírica foi reverberada posteriormente por dois outros discípulos, Klatt e Meister em obra monográfica sobre a matéria. Quando se trata da dimensão religiosa, essa sorte de qualificação não é problemática, sendo, ao contrário, legitimadora. No campo da filosofia, da ciência e da reflexão teórica em geral, trata-se de algo desastroso, pois tende a minar um dos pressupostos da ciência e de outras formas de conhecimento reflexivo, a "limitacionalidade", a saber, o suposto de que o conhecimento nunca está esgotado. Virgílio Afonso da Silva, em seu artigo "O Supremo Tribunal Federal precisa de Iolau: Resposta às objeções de Marcelo Neves ao sopesamento e à otimização", propõe-se apresentar uma crítica ao meu livro "Entre Hidra e Hércules". Apresentarei a seguir meus comentários às críticas de Virgílio Afonso da Silva ao meu livro, para comprovar, com argumentos claros, de que se trata de objeções equivocadas e que, às vezes, me parecem apressadas, pois simplificam (e, em parte, deformam) a minha linha de raciocínio de maneira um tanto retórica para imputar-lhe a aparência de uma fragilidade, a rigor, inexistente.

Palavras-Chave: Filosofia do Direito; Regras e princípios; Precedentes e sopesamento.

AbSTRACT: In a 2008 article, one of Robert Alexy's disciples, Lorenzo Zucca pontificated Alexy as the "prophet of proportionality doctrine." This panegyric labeling was reverberated later by two other disciples, Klatt and Meister in a

${ }^{1}$ Doutor em Direito pela Universidade de Bremen. Pós-Doutor na Faculdade de Ciência Jurídica da Universidade de Frankfur e no Departamento de Direito da London School of Economics and Political Science. E-mail: marceloneves@unb.br. 
monographic work on the subject. When it comes to the religious dimension, this sort of qualification is not problematic, but rather legitimizing. In the field of philosophy, science, and theoretical reflection in general, this is disastrous, since it tends to undermine one of the presuppositions of science and other forms of reflective knowledge, "limitationality," namely, the assumption that knowledge is never exhausted. Virgílio Afonso da Silva, in his article "The Federal Supreme Court needs Iolau: Response to Marcelo Neves's objections to the balancing and optimization", proposes to present a review of my book "Between Hydra and Hercules." comments to Virgílio Afonso da Silva's criticism of my book, to prove, with clear arguments, that these are mistaken objections and that sometimes they seem to me hurried, since they simplify (and, in part, distort) my line of rationale in a somewhat rhetorical way to impute to him the appearance of a fragility, strictly, non-existent.

KEYWORDS: Philosophy of law; Rules and principles; Precedents.

\section{INTRODUÇÃO}

Em um artigo de 2008, um dos discípulos de Robert Alexy, Lorenzo Zucca pontificou Alexy como o "profeta do sopesamento estruturado" (ZUCCA, 2008, p. 28). Essa rotulação panegírica foi reverberada posteriormente por dois outros discípulos, Klatt e Meister em obra monográfica sobre a matéria (KLATT; MEISTER, 2012a, p. 04). Quando se trata da dimensão religiosa, essa sorte de qualificação não é problemática, sendo, ao contrário, legitimadora. No campo da filosofia, da ciência e da reflexão teórica em geral, trata-se de algo desastroso, pois tende a minar um dos pressupostos da ciência e de outras formas de conhecimento reflexivo, a "limitacionalidade", a saber, o suposto de que o conhecimento nunca está esgotado (LUHMANN, 1990, p. 392 ss). Portanto, a linguagem da profecia é deslegitimadora no âmbito de saberes científicos ou teóricos. A esse respeito, Max Weber já alertava na sua célebre palestra sobre "Ciência como Vocação", ao arguir, nos seguintes termos: "A ciência não é produto de revelações, nem é graça que um profeta ou um visionário houvesse recebido para assegurar a salvação das almas" (WEBER, 1975, p. 33 [trad. bras. 2011, p. 58]). Antes, Friedrich Hegel já a pontava similarmente: “O filósofo não se afina com profecias [...]. A filosofia ocupa-se daquilo que é [...] da razão, e com isto já temos muito o que fazer" (HEGEL, 1917 [1837], p. 200)². Sem dúvida, toda profecia fere a forma como o saber científico, filosófico ou afim processa a contingência do mundo, pois ela tem um potencial paralisante dessa forma de processamento e da curiosidade a ela inerente.

Virgílio Afonso da Silva, em seu artigo "O Supremo Tribunal Federal precisa de Iolau: Resposta às objeções de Marcelo Neves ao sopesamento e à otimização", , propõe-

\footnotetext{
${ }^{2}$ Bobbio (1995 [1984], p. 03 [trad. bras. 1986, p. 17]) invocou essas passagens de Weber e Hegel.
}

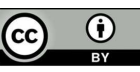


se apresentar uma crítica ao meu livro "Entre Hidra e Hércules" (NEVES, 2013), nos seguintes termos: "Neste breve artigo, pretendo defender minhas ideias em face das objeções que o autor suscita em seu livro para mostrar que Marcelo Neves, de um lado, não tem razão nessas objeções e, de outro, não oferece de fato uma alternativa àquilo que ele chama de 'modelos ainda dominantes'" (SILVA, 2016, p. 98, grifei). Já, nesse ponto de partida, verifica-se uma dificuldade para se dar a resposta ao autor do artigo, pois ocorre uma superposição entre as ideias do discípulo e do mestre (ou profeta?). Em verdade, no plano primariamente teórico, dos capítulos I a III do meu livro, minhas objeções foram feitas às teorias clássicas dos princípios e a dois autores mais recentes, Ronald Dworkin e Robert Alexy. Nesse plano, as alusões a Virgílio Afonso da Silva foram marginais, referindo-se à sua recepção no Brasil da teoria de Alexy. Só no capítulo IV, quando me dedico à recepção acrítica e superficial da teoria dos princípios no Brasil, realmente faço objeções a Silva. O ponto foi enfatizar que, nesse plano de aplicação das teorias, ele se envolveu no debate de uma maneira que carregou vício similar aos dos seus colegas brasileiros: o fascínio acrítico por teorias formuladas em outro contexto.

Apesar da dificuldade ou mesmo impossibilidade de distinguir o que é simples defesa do mestre ou autodefesa do discípulo no plano teórico, apresentarei a seguir meus comentários às críticas de Virgílio Afonso da Silva ao meu livro, para comprovar, com argumentos claros, de que se trata de objeções equivocadas e que, às vezes, me parecem apressadas, pois simplificam (e, em parte, deformam) a minha linha de raciocínio de maneira um tanto retórica para imputar-lhe a aparência de uma fragilidade, a rigor, inexistente. Minha argumentação terá uma ordem diversa da apresentada no artigo ora comentado. Em um primeiro momento, responderei à crítica de Virgílio Afonso da Silva de que eu teria confundido o nível teórico e a prática institucional (tópico II). A seguir, tratarei de suas restrições à metáfora que dá título ao livro (tópico III). Em um terceiro passo, enfrentarei as suas objeções referentes à minha compreensão da diferença entre regras e princípios, inclusive à sua censura à concepção de híbrido, conforme se apresentam nos tópicos 3, 4 e 5 do seu artigo (tópico IV). Daí partirei para uma breve referência aos seus comentários às colisões intraprincípios (tópico V). Em sequência, adentrarei mais pormenorizadamente nas suas restrições à minha crítica à otimização (tópico VI). Dando continuidade e saindo da dimensão primariamente teórica da própria compreensão da função e estrutura dos princípios e das regras, considerarei as respostas ao que Silva chamou de "críticas esparsas", o que, na verdade, são críticas concentradas no quarto capítulo à sua inserção enviesada e contraditória no debate em torno da aplicação disparatada da teoria dos princípios, da proporcionalidade, do sopesamento e de temas afins na doutrina e na prática brasileiras nas duas décadas anteriores; em conexão, considerarei os comentários de Virgílio Afonso da Silva sobre o meu tratamento dos abusos de princípios no Brasil de hoje e de antes (tópico VII). Por fim, considerarei as suas restrições à metáfora do Juiz Iolau (tópico VIII), para concluir com uma breve observação sobre o risco de se tornar um "enviado" de "profeta" (tópico IX). 


\section{DIFERENÇA ENTRE PLANO TEÓRICO, APLICAÇÃO DOUTRINÁRIA E PRÁTICAS INSTITUCIONAIS}

No início de seu artigo, Virgílio Afonso da Silva afirma que, no tópico 7, procurará mostrar que, "em vários momentos, Neves não distingue claramente que problemas são teóricos e quais são institucionais" (SILVA, 2016, p. 98, grifei), mas no tópico 7 do artigo, sob o título "O plano normativo e o plano institucional", sustenta que algumas das minhas objeções "parecem misturar indevidamente os planos normativo e institucional" (SILVA, 2016, p. 106, grifei). Dessa maneira, parece confundir o teórico com o normativo, o que dificulta a compreensão de sua crítica. A teoria está no plano da reflexão (conceitual do sistema jurídico), o normativo está no plano da prática social (práxis), mesmo quando esteja no nível reflexivo (dos processos jurídicos) ${ }^{3}$. Apesar dessa confusão conceitual, responderei a essa restrição de Silva em dois passos.

Em primeiro lugar, é difícil separar o plano teórico das práticas institucionais de uma maneira absoluta. Teorias se desenvolvem com base em práticas institucionais e essas são influenciadas por aquelas. O que pode ocorrer é uma distinção analítica entre teoria da norma e prática institucional, de caráter relativo, para que se assumam, primariamente (não exclusivamente) uma das perspectivas de observação. Não assumo a teoria clássica da separação absoluta entre linguagem objeto e metalinguagem, como dois níveis reciprocamente incontamináveis. O que ocorre é uma retroalimentação ou circulação entre teorias e práticas institucionais, que podem, porém, redundar, às vezes, em bloqueios ou desacoplamentos. Daí por que incluí o quarto capítulo.

Quanto a uma separação entre os planos normativo e institucional, parece-me que minha objeção deve ser mais contundente. O normativo, seja no nível abstrato ou no concreto, permeia as instituições, embora não se confunda com elas nem com as respectivas práticas. As normas constituem uma das dimensões formadoras do institucional e as instituições são construtoras de normas. Sendo caritativo no sentido de Donald Davidson (1984, p. 197) ${ }^{4}$, penso que Virgílio Afonso da Silva, ao falar de planos institucional e normativo, quis se referir à "teoria da norma" em face da prática institucional. Mas a esse respeito, mantenho a crítica do parágrafo anterior e rejeito peremptoriamente a seguinte a afirmação de Virgílio Afonso da Silva: "o exemplo da tensão entre diferentes planos institucionais independe da teoria das normas adotada" (SILVA, 2016, p. 107). O que procurei apontar é que o plano da teoria da norma e o plano das práticas institucionais, embora não se confundam, são interdependentes. Uma teoria da norma que tenha um déficit de reflexão pode ter efeitos negativos na prática institucional, podendo até mesmo servir como uma ideologia que esconde a complexidade do mundo jurídico e social. Uma prática jurisdicional ou institucional em geral que adote teorias frágeis pode ser eivada de inconsistências insuperáveis, assim como, por outro lado, o manuseio institucional equivocado de teorias de grande relevância prática pode ter impacto destrutivo no direito. $O$ que me parece

${ }^{3}$ Para entender o desenvolvimento dos conceitos de reflexão e reflexividade como mecanismos de autorreferência do Direito, ver Luhamnn (1984, p. 601, 610 ss) e Neves (2007, p. 131-133).

4 Em tradução livre: "Caridade é imposta a nós; gostemos ou não, se queremos entender outros, devemos considerá-los corretos na maioria das matérias". No original: "Charity is forced on us; whether we like or not, if we want to understand others, we must count them right in most matters". 
inadmissível é contar com a existência de "teorias puras", conforme uma distinção radical entre sujeito e objeto, entre teoria e prática, porque teorias são também construtoras do seu objeto, assim como uma teoria da norma é, em parte, construtora do sentido que as normas adquirem na prática.

Embora sem aceitar essa separação ingênua entre planos da teoria e da instituição ou entre planos normativo e institucional nos termos proposto por Silva, não deixei de fazer uma distinção analítica rigorosa entre a reflexão primária no plano da teoria das normas nos três primeiros capítulos do livro e a consideração da sua recepção enviesada na doutrina (capítulo 4.1) e na prática jurisprudencial brasileira (capítulo 4.2). Procedi, portanto, a uma distinção entre os planos da teoria em geral, da doutrina ou dogmática e da prática jurídica no Brasil. Isso fica claro quando adianto, na Introdução, que meu trabalho "concentrar-se-á criticamente no debate jurídicoconstitucional que se desenvolve desde os anos 1970 do século XX sobre princípios e regras constitucionais, particularmente sob o impacto das obras de Ronald Dworkin e Robert Alexy, para, a partir daí, oferecer um modelo alternativo e apontar para os limites e equívocos da recepção da principiologia jurídica na doutrina e prática constitucional brasileira" (NEVES, 2013, p. XXV). Daí segue a divisão dos capítulos, ficando concentradas no capítulo IV as questões doutrinárias e práticas localizadas da recepção no Brasil.

Uma prova clara disso é que, no capítulo IV, não há mais nenhuma objeção direta às teorias de Dworkin e Alexy. Ao contrário, na página 192, cito Alexy, em meu favor, para criticar uma ideia disseminada na doutrina e na prática jurídicas brasileiras de que os princípios sempre prevalecem sobre as regras. Por outro lado, diferentemente do entendimento de Virgílio Afonso da Silva no início do seu artigo, de que se trata de objeções às suas ideias, e no começo do tópico 1, de que "em inúmeras partes do livro de Marcelo Neves, meus trabalhos são usados como contraponto àquilo que ele pretende defender" (SILVA, 2016, p. 99), minhas críticas aos seus trabalhos concentram-se no capítulo IV do meu livro, entre as páginas 182 e 189, quando trato do seu envolvimento enviesado no debate sobre a recepção disparatada da teoria dos princípios, da ponderação, da proporcionalidade e de temas afins na doutrina constitucional brasileira. Nas demais partes do livro, minhas referências a ele são marginais, incluindo-se praticamente nas referências à literatura secundária à obra de Alexy ${ }^{5}$.

Enfim, o argumento de Virgílio Afonso da Silva a respeito de uma suposta mistura de planos de abordagem em meu livro, além de induzir a erro e basear-se em frágeis pressupostos, não encontra respaldo em uma leitura mais detida da obra em questão.

\section{O SENTIDO DA METÁFORA “ENTRE HidRA E HÉRCULES"}

Outro aspecto evidentemente infundado na resposta de Virgílio Afonso da Silva diz respeito às restrições que faz, no tópico 2 de seu artigo, à metáfora "entre Hidra e

\footnotetext{
5 Uma exceção é a crítica contida na página 153, nota 149 , quando faço restrições à sua aplicação da teoria de Chang (2002) no âmbito do modelo de sopesamento proposto por Robert Alexy. Voltarei a esse tema infra no tópico VI.
} 
Hércules", que usei para inverter a suposição de Dworkin ao considerar que os argumentos baseados em princípios servem para fechar a cadeia do raciocínio jurídico quando as regras forem insuficientes para resolver o caso, especialmente nos chamados "casos difíceis". Meu argumento, desenvolvido em todo trabalho com base em certos pressupostos teóricos da teoria dos sistemas, é no sentido de que os princípios servem antes para abrir a cadeia argumentativa do que para conduzi-la ao fechamento, o que seria mais apropriado às regras. Silva afirma:

Há claramente um passo injustificado no raciocínio de Neves, quando ele, ao reconstruir a ligação do juiz Hércules (de Dworkin) com os princípios constitucionais, conclui que seria possível dizer que os princípios são hercúleos. O fato de Hércules ser encarregado de identificar todos os princípios jurídicos relevantes para a decisão de um dado caso não nos autoriza classificar os princípios como hercúleos. Talvez a tarefa de Hércules seja, como não poderia deixar de ser, hercúlea, mas os princípios não são hercúleos. Até porque Hércules não tem como tarefa apenas identificar e manejar princípios, mas também regras, precedentes, legislação. Isso não torna regras, precedentes e legislação hercúleos. Hercúleo continua sendo simplesmente o trabalho de Hércules, e princípios são apenas um entre tantos outros 'materiais jurídicos' que ele maneja.

Ao que parece, a estipulação dos princípios como hercúleos serve para justificar a novidade: uma inversão no papel dos princípios e das regras constitucionais. É claro que há um paralelo entre Hércules cortando as cabeças de Hidra e as regras restringindo a amplitude dos princípios. Mas hercúleo continua a ser o papel do juiz, Hércules ou não. (SILVA, 2016, p. 102)

É claro que quando se inverte uma metáfora, não se deve considerar "literalmente" a forma original de sua formulação. O que eu procuro dizer é que, em Dworkin, o juiz ideal Hércules é aquele relacionado primariamente aos princípios, de tal maneira que, na minha inversão reconstrutiva, os princípios têm um quê de hercúleo em sua teoria. $\mathrm{Na}$ minha metáfora, os princípios relacionam-se primariamente (não exclusivamente) com a figura de Hidra (abertura normativa), enquanto as regras estão associadas primariamente (não exclusivamente) à figura de Hércules (fechamento normativo).

Parece-me um truísmo a alegação de Virgílio Afonso da Silva de que "Hércules não tem como tarefa apenas identificar e manejar princípios, mas também regras, precedentes, legislação" e que, portanto, "isso não torna regras, precedentes e legislação hercúleos". É claro que qualquer juiz, mesmo idealmente considerado, tem que manejar os diversos aspectos de uma ordem jurídica. O que afirmo é que Hércules só se torna relevante na teoria de Dworkin (1975) nos casos difíceis, quando só então é preciso realmente, para ele, levar os princípios a sério. Nesse particular, cabe observar que Dworkin introduziu a figura do Juiz Hércules em seu artigo "Casos difíceis" [Hard Cases], publicado em 1975 e republicado no capítulo IV do seu livro “Levando os 
direitos a sério" (DWORKIN, 1978, p. 80-130 [trad. bras. 2002, p. 128-203]) ${ }^{6}$. Nesse capítulo, ele esclarece: "Contudo, se o caso em questão for um caso difícil, em que nenhuma regra estabelecida dita uma decisão em qualquer direção, pode parecer que uma decisão apropriada possa ser gerada seja por princípios, seja por políticas" (DWORKIN, 1978, p. 83 [trad. bras. 2002, p. 131]). (Considere-se que, no sentido amplo e "genérico", os princípios incluem as políticas na obra inicial de Dworkin (1978, p. 22 [trad. bras. 2002, p. 36]), que só "ocasionalmente" distingue entre princípios e políticas como padrões do direito.) Assim, o juiz Hércules aparece na teoria de Dworkin basicamente como aquele que tem a árdua tarefa de identificar e aplicar, nos "casos difíceis", os "princípios que 'subjazem' às regras positivas do direito, ou que nelas estão 'inscritos'" (DWORKIN, 1978, p. 105 [trad. bras. 2002, p. 164-165]). Esse é o seu distintivo. Ele é um juiz filósofo orientado primariamente, em termos normativos, por princípios: "Podemos, portanto, examinar de que modo um juiz filósofo poderia desenvolver, nos casos apropriados, teorias sobre aquilo que a razão legislativa e os princípios jurídicos requerem" (DWORKIN, 1978, p. 115 [trad. bras. 2002, p. 180]). O Hércules dworkiniano parte de que "a força gravitacional de um precedente define-se pelos argumentos de princípio que lhe dão sustentação" (DWORKIN, 1978, p. 105 [trad. bras. 2002, p. 165]).

Embora, mais tarde, em repostas a críticas, Dworkin alegue defensivamente que "seu método [de Hércules] aplica-se igualmente bem a casos fáceis", ele relativiza sua asserção afirmando que, nesses casos, como "as repostas às perguntas que coloca são então evidentes, ou pelo menos parecem sê-lo, não sabemos absolutamente se há alguma teoria em operação", para sugerir que o método de Hércules só se torna relevante quando algo que seria "caso fácil" torna-se "caso difícil" com o tempo (DWORKIN, 1986, p. 354 [trad. bras. 2003, p. 423-424]). Em todo caso, a relação particular e primordial de Hércules com os princípios mantém-se incólume: "Hércules serve a nosso propósito porque é livre para concentrar-se nas questões de princípio que, segundo o direito como integridade, formam o direito constitucional que ele aplica." (DWORKIN, 1986, p. 380 [trad. bras. 2003, p. 454]). Portanto, a minha leitura e a respectiva revisão da metáfora de Dworkin são perfeitamente oportunas: para ele, os princípios são hercúleos; para mim, ao contrário, as regras são hercúleas, enquanto os princípios associam-se primordialmente ao mito da Hidra.

Enfim, ao considerar que em Dworkin, de forma contundente na sua formulação inicial, o juiz Hércules só se torna relevante quando se trata de identificar e aplicar os princípios em um caso concreto, inferi metaforicamente, sem a literalidade exigida por Virgílio Afonso da Silva, que os princípios são primariamente hercúleos na obra do autor norte-americano, propondo daí uma inversão da metáfora. Mas seria um absurdo se dissesse, como me parece disparatado que se infira ter dito, que o juiz Hércules dworkiniano só cuidaria de princípios, não se ocupando de regras, precedentes, legislação etc. Não se trata, conforme Luhmann (1990, p. 245 ss), de exclusividade de um branco e preto da literalidade, de submissão dogmática à linguagem de um outro, mesmo sendo ele tão reputado (a reputação é um código secundário na área do saber científico ou acadêmico). Trata-se de uma metáfora para

${ }^{6}$ Ele trata especificamente de “Hércules" nas páginas 105-130 [trad. bras. 2002, p. 165-203]). 
rebater a ideia de que os princípios fecham a cadeia argumentativa ao serem identificados e aplicados pelo Juiz Hércules dworkiniano. Ao contrário, repito, a minha metáfora diz respeito à tese de que, na cadeia da concretização normativa, os princípios jurídicos e constitucionais estão associados primariamente (não exclusivamente) à abertura cognitiva e normativa do sistema jurídico e aos argumentos substantivos, enquanto as regras relacionam-se primariamente (não exclusivamente) com o fechamento normativo do direito e à argumentação formal (NEVES, 2013, p. 227). Para considerar apropriadamente esse paradoxo precisa-se de uma abordagem acurada, que considere a complexidade e as nuances do modelo.

\section{REGRAS, PRINCÍPIOS E HÍBRIDOS}

\section{A crítica à generalidade como critério de distinção entre princípio e regras}

Eu parto de um conceito de princípios e regras que se baseia no caráter reflexivo dos princípios em relação às regras e mediato em relação à (norma de) decisão do caso (observação de segunda ordem), por um lado, e no potencial das regras de servirem de critério definitivo para a solução de um caso (observação de primeira ordem), por outro (NEVES, 2013, p. 120 ss). Nesse sentido, faço restrições às teorias que partem do critério da generalidade para distinguir entre princípios e regras.

Virgílio Afonso da Silva, no tópico 3 do seu artigo, tomando um extrato descontextualizado de meu trabalho, alega que, ao afirmar que a norma contida no art. 5, inciso XXXIX, da Constituição Federal, é uma regra e não um princípio porque "serve como critério definitivo para a tomada de decisão solucionadora de um caso" (NEVES, 2013, p. 23; SILVA, 2016, p. 103), "Neves [...] peca (sic) por uma certa circularidade" (SILVA, 2016, p. 102-103). No trecho citado, eu suporia que os conceitos de princípio e regras que adoto "seriam unanimemente aceitos", para arrematar com o óbvio: "Em outras palavras, eu não posso usar o meu próprio conceito de regra (ou de princípio) para rejeitar a inclusão, em uma classificação baseada em critérios distintos, dessa ou daquela norma na categoria 'regra' (ou 'princípio')" (SILVA, 2016, p. 103). Por fim, cita um trabalho anterior de sua autoria, onde apenas se enfatiza novamente uma obviedade: "Classificações ou são coerentes e metodologicamente sólidas, ou são contraditórias - quando, por exemplo, são misturados diversos critérios distintivos - e, por isso, pouco ou nada úteis" (SILVA, 2016, p. 103).

Em primeiro lugar, cabe insistir no esclarecimento de que a distinção entre linguagem objeto e metalinguagem é relativa, não cabendo uma separação radical de níveis, no mínimo no campo do direito e das ciências sociais, que trabalham com linguagem ordinária, especializada ou não. Trata-se daquilo que Douglas Hofstadter chama de "voltas estranhas" e "hierarquias entrelaçadas" (HOFSTADTER, 1979, p. 21 ss, 648 ss [trad. bras. 2001, p. 23 ss, 751 ss]). De forma mais elementar, as proposições cognitivas são construtivas do "objeto". (De forma mais clássica, que não adoto, poderia, na tradição kantiana, dizer-se que o "sujeito" constrói o "objeto" do conhecimento $^{7}$ - mas Silva parece prekantiano, sem que haja nada de pejorativo nisso).

7 Ver, por exemplo, Kant (1990 [1781/1978', vol. 1, p. 139-141, 168 [B 137-139, A 107]). 
Por sua vez, entre proposição doutrinária ou teórica sobre a norma e a própria norma há uma certa circularidade (NEVES, 2013, p. 03). Esse tipo de circularidade é não apenas inevitável, mas necessária às transformações teóricas e doutrinárias, contribuindo para a aquisição de novos conhecimentos.

Entretanto, Virgílio Afonso da Silva imputa-me o "pecado" de uma circularidade vulgar. Ela não procede, pois não parti da suposição de uma aceitação unânime do meu critério ou qualquer outro nem caí em uma forma inocente de tautologia.

O processo de ordenar o material de conhecimento é um processo seletivo. Quando se propõe uma classificação ou uma conceituação deve-se buscar algo operativo, útil e consistente, obviamente. Para isso, tem-se que apontar para os limites da operatividade de outras classificações. Não se trata apenas de assumir dogmaticamente um critério já existente - "caso, no entanto, se prefira usar os critérios estabelecidos por Alexy" (SILVA, 2016, p. 103) - e ser coerente dentro desse critério. Quando se assume ou propõe um critério definitório ou ordenador, faz-se mister que se afastem os demais, apontando para a superioridade da força operativa e para o maior grau de consistência desse critério em relação a critérios concorrentes.

O trecho que Virgílio Afonso cita, descontextualizadamente, refere-se ao primeiro parágrafo em que passo a criticar o critério da generalidade. Cito exatamente Alexy (porque, nesse ponto, há uma convergência conceitual entre o meu modelo e o dele), na primeira oração, para lembrar, em um gesto de honestidade intelectual, que também ele traz um exemplo referente à anterioridade penal - prevista no art. 103(2) da Constituição alemã ("Lei Fundamental") similarmente ao art. 5o, inciso XXXIX, da Constituição brasileira - como insuscetível de ser enquadrado como princípio, para apontar os limites da teoria da generalidade. Ele afirma algo que não foi transcrito no meu livro, mas que agora exige uma transcrição: "A existência de normas de alto grau de generalidade que não são princípios demonstra que o critério da generalidade é apenas relativamente correto" (ALEXY, 1986, p. 92 [trad. bras. 2008, p. 109]). Teria Alexy caído no "pecado" da "circularidade" com essa afirmativa? Evidentemente, se eu tomasse isoladamente essa passagem como Silva tomou o meu trecho, poderia dar uma resposta afirmativa e fazer censuras óbvias a Alexy. Mas temos que considerar o autor no contexto do processo seletivo de inclusões e exclusões que distingue o seu universo conceitual.

Admito que o exemplo de anterioridade penal talvez não seja o mais feliz para esclarecer a fragilidade e inconsistência do critério da generalidade, pois sempre ressurgem controvérsias sobre sua tipificação normativa. Meu argumento, porém, parecendo-me nesse particular mais acurado do que as críticas de Alexy, vai além. $\mathrm{Na}$ página seguinte do livro, eu me refiro aos princípios setoriais, exemplificando com $\mathrm{o}$ art. 146, inciso III, da Constituição Federal, que prescreve "o adequado tratamento tributário ao ato cooperativo praticado pelas sociedades cooperativas" (NEVES, 2013, p. 24). Comparo esse dispositivo com o art. 5ㅇ, inciso XLV, da Constituição Federal, o qual estabelece que "nenhuma pena passará da pessoa do condenado". Meu argumento é que mesmo aqueles que partissem do critério da generalidade teriam dificuldade de dizer que o primeiro dispositivo (menos genérico) contém uma regra, enquanto o segundo, mais genérico, referindo-se diretamente a todo ser humano, seria um princípio. Haveria um embaraço decorrente da fragilidade e inconsistência do 
critério. Na mesma linha de raciocínio, comparei o preceito setorial da independência do juiz (CF, art. 95, caput) com o dispositivo concernente à proibição de qualquer distinção "entre brasileiros natos e naturalizados, salvo nos casos previstos nesta Constituição" (CF, § 2o do art. 12) (NEVES, 2013, p. 24-25). Também haveria embaraço, para os que defendem o critério da generalidade, em atribuir aos primeiros (menos genérico, setorial) o caráter de regra e considerar o segundo (mais genérico) com base no seu próprio critério. Mas não deixei de fazer uma concessão: em comparação com as regras que neles se apoiam e lhes dão suporte prático, os princípios sempre serão mais gerais do que elas, mesmo que sejam setoriais, como no caso da relação entre regras-garantia da inamovibilidade e da vitaliciedade e o princípio da independência do juiz. Mas no geral, procurei apontar a fragilidade e a inconsistência do critério da generalidade.

O que Virgílio Afonso da Silva fez foi isolar uma passagem sem considerar o contexto, para imputar-me o "pecado" da circularidade, mas isso ele também poderia fazer com o trecho acima citado de Alexy. Nessa altura do trabalho, eu estava a afastar os critérios concorrentes dos modelos que chamei de "clássicos", apontando para as suas deficiências, assim como fiz o mesmo com os modelos de Dworkin e Alexy, que chamei de "ainda dominantes" no capítulo segundo do livro. Esboçado, na Introdução, os critérios que adoto, fiz a tarefa seletiva e crítica em face dos modelos concorrentes, excluindo elementos incompatíveis, mas, ocasionalmente, incluindo outros. É assim que se propõe ou se adota um modelo conceitual. Do contrário, basta partir acriticamente de um autor proeminente. Mas esse não me parece um caminho academicamente produtivo, apesar de todas as aparências que resultam da obediência e coerência com os dignos de reputação.

\section{Por uma nova conceituação de regras e princípios além de Robert Alexy?}

No tópico 5 do seu artigo, Virgílio Afonso da Silva critica a minha diferença entre regras e princípios, defendendo a correção e consistência da divisão introduzida por Robert Alexy. Silva cita um texto anterior de sua autoria em defesa do seu professor alemão, que reproduz para me criticar nos seguintes termos:

O fato de a aplicação de princípios nem sempre exigir um sopesamento não altera em nada o fato de que a aplicação de princípios pode exigir um sopesamento. Esse é o ponto decisivo: apenas normas que são passíveis de serem sopesadas podem ser otimizadas e, por conseguinte, classificadas como princípios. (SILVA, 2016, p. 105, grifei)

Ele critica, então, a posição de Aarnio em caracterizar a liberdade de expressão como "um princípio que é como uma regra", que poderia eventualmente ser caracterizado antes com um híbrido na minha visão (NEVES, 2013, p. 105-107), e dispara:

E a razão é simples: a capacidade de ser aplicada diretamente e resolver casos não é um critério diferenciador entre regras e princípios, 
ao menos não na versão defendida por Alexy. Não é possível, portanto, criticar a sua teoria por não aceitar híbridos se, na verdade, os híbridos só surgem porque um critério novo, estranho à teoria, foi adicionado por Neves. Seu novo critério pode até ser útil para outros fins analíticos, mas não para criticar uma classificação que, boa ou não, foi feita com base em outro critério. (SILVA, 2016, p. 105)

Não se trata, no meu caso de uma aceitação dogmática de uma teoria ou outra, de isolar uma teoria das críticas de qualquer outro modelo "analítico", cada um seguindo autarquicamente seus próprios critérios. Trata-se de apontar os limites de um modelo concorrente, nesse caso, o de Robert Alexy, também sem rejeitá-lo dogmaticamente.

Em primeiro lugar, eu não adoto a formulação de Aarnio com as expressões "princípios que são como regras" ou "regras que são como princípios". Meu argumento é que, prima facie, certas normas podem ser "híbridos", dada a dificuldade de enquadramento típico como regra ou como princípio (NEVES, 2013, p. 106). Evidentemente, a posteriori, no final do processo concretizador em um caso controverso, pode-se sempre definir o que atuou como norma reflexiva (princípio) ou norma definitiva (regra) para a solução do caso (NEVES, 2013, p. 106). Mas relativizo a caracterização de Aarnio, nesse contexto, tanto para afirmar que as normas que ele designa como "regras que são como princípios" podem ser definidas como "regras incompletas no sentido de Alexy", quanto para conceder que os "princípios que são como regras" podem ser considerados, "em última instância, regras" (NEVES, 2013, p. 106-107). Eu aponto, nesse contexto, para as dificuldades de ordenação prima facie em uma dessas categorias, com muita cautela, pois a função e a estrutura de uma norma depende também da ordem jurídica em que ela está integrada.

Silva equivoca-se quando sugere em seu texto que minha crítica a Alexy seria relativa ao fato de que este autor teria distinguido os princípios das regras por serem eles sopesáveis. No meu trabalho enfatizo claramente que Alexy (1986, p. 121 [trad. bras. 2008, p. 140]) admite a existência de "regras incompletas", que são sopesáveis, citando a própria passagem de Alexy (NEVES, 2013, p. 77-78). Minha restrição a Alexy refere-se ao questionamento que faço na seguinte passagem:

É claro que no caso de mera observância cotidiana e de simples aplicação burocrática rotineira do direito ainda não é relevante a distinção entre o caráter prima facie e definitivo da regra. Supõe-se completude da regra.

[...]

Se, porém, surgirem controvérsias em torno da regra a aplicar no processo de concretização constitucional, a distinção entre o caráter prima-facie e o definitivo das regras invocadas é relevante. O enunciado completo da regra só pode ser formulado no final da cadeia concretizadora, servindo como fundamento definitivo da norma de decisão do caso.

$[\ldots]$

5 JOURNAL OF INSTITUTIONAL STUDIES 1 (2019)

Revista Estudos Institucionais, v. 5, n. 1, p. 269-316, jan./abr. 2019 
Isso significa que o enunciado completo da regra a aplicar, como fundamento definitivo da decisão, salvo na mera observância cotidiana ou aplicação rotineira do direito, só se alcança no final do processo de concretização, pressupondo uma pluralidade conflituosa de controvérsias argumentativas em torno da solução do caso, onde a dimensão do peso desempenha um certo papel. Parece-me que, de alguma maneira, ao admitir regras incompletas, dependentes de ponderação, Alexy admite implicitamente que, neste particular, a diferença entre princípios e regras é, antes, gradual, embora não seja essa a sua intenção (NEVES, 2013, p. 78, 80-81).

Nesse argumento, antes cauteloso, cuida-se de afirmar que a diferença entre princípios e regras é irrelevante nos casos "rotineiros" e que, considerando a relevância dessa distinção nos casos controversos, também chamados de "difíceis" ou "marginais", quando do início da cadeia concretizadora, ou seja prima facie, não apenas os princípios, mas também as regras são sopesáveis. Essas só se tornam completas e funcionam como "razões" ou critérios definitivos, então, no final da cadeia concretizadora. No contexto do meu argumento a esse respeito, analiso alguns casos ou hipóteses em que se apresenta claramente a colisão entre regras e se torna necessário o sopesamento entre elas, sem que a regra superada precise ser considerada inválida.

Além disso, seria um absurdo se tivesse dito que, conforme a obra de Robert Alexy, os princípios, em todo caso de aplicação, entrariam em colisão com outros princípios (ou com uma "regra incompleta") e, portanto, seriam sempre sopesados. Isso sugere equivocadamente Silva nos trechos acima citados. Evidentemente, os princípios, tanto na teoria de Alexy quanto na minha, podem ser aplicados, em diversas situações, sem que seja necessário sopesamento, até mesmo para identificar a regra a ser aplicada imediatamente à solução do caso. No que me afasto de Alexy, nesse particular, concerne a uma ambivalência em sua obra. De um lado, ele afirma em trechos por mim transcritos:

Princípios são sempre razões prima facie e regras são, se não houver o estabelecimento de alguma exceção, razões definitivas.

$[\ldots]$

Nesse sentido, é possível afirmar que sempre que um princípio for, em última análise, uma razão decisiva para um juízo concreto de deverser, então, esse princípio é o fundamento de uma regra, que representa uma razão definitiva para esse juízo concreto. Em si mesmos, princípios nunca são razões definitivas. (ALEXY, 1986, p. 90 e 92 [trad. bras. 2008, p. 106 e 108]; NEVES, 2013, p. 68-69, grifei)

E eu acrescento agora outra parte desse mesmo parágrafo:

8 "Marginais" nos termos de Carrió (1986, p. 55-61), em oposição a "casos típicos". 
Princípios são, ao contrário [de regras], sempre razões prima facie. Isoladamente considerados, eles estabelecem apenas direitos prima facie. (ALEXY, 1986, p. 91-92 [trad. bras. 2008, p. 108])

Nesse contexto, apontei que Alexy até mesmo corrobora a asserção de Joseph Esser, segundo a qual o "princípio, conforme a noção continental, não é, ele mesmo, 'diretiva', mas fundamento, critério e justificação da diretiva" - ao citar esse trecho de Esser (1956, p. 51-52), Alexy (1986, p. 92 [trad. bras. 2008, p. 108]) exclui 'conforme a

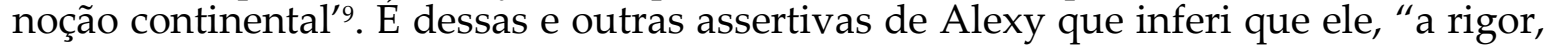
admite que os princípios só podem ser razões diretas de regras e, por intermédio destas, razões indiretas de juízos concretos de dever-ser" (NEVES, 2013, p. 69). Pensei, então que, nesse específico ponto, poderia haver uma convergência entre nossas teorias, e inclusive com a de Esser. Mas, em outro trecho de sua obra, deparei-me com a seguinte afirmativa:

Um dos critérios para a diferenciação entre regras e princípios [...] classifica os princípios como razões para regras, e somente para regras. Se esse critério fosse correto, princípios não poderiam servir como razões diretas para decisões concretas. A compreensão de que os princípios são razões para regras e as regras são razões para decisões concretas (normas individuais) tem, à primeira vista, algo de plausível. Mas, a partir de uma análise mais detalhada, essa concepção mostra-se incorreta. Regras podem ser também razões para outras regras e princípios podem também ser razões para decisões concretas. (ALEXY, 1986, p. 91 [trad. bras. 2008, p. 107], grifei)

O que me parece incorreto e contraditório com a ideia acurada de que os "princípios nunca são razões definitivas", nessa passagem, é afirmar ser "incorreta" a concepção de que os "princípios não poderiam servir como razões diretas para decisões concretas". É claro que os princípios podem ser razões decisivas de decisão concreta, mas são razões indiretas. Como poderiam ser razões diretas se nunca poderiam ser razão definitiva? Esse trecho contradiz o trecho acima citado de Esser, trazido à baila por Alexy para corroborar sua ideia de os princípios nunca serem razões definitivas, ou seja, que princípio "não é, ele mesmo, 'diretiva', mas fundamento, critério e justificação da diretiva". Mas contradiz também o trecho transcrito acima em que Alexy sustenta que "sempre que um princípio for, em última análise, uma razão decisiva para um juízo concreto de dever-ser, então, esse princípio é o fundamento de uma regra, que representa uma razão definitiva para esse juízo concreto". Inicialmente, em postura caritativa, eu relevei essa questão, relativizando-a e tratandoa como se tivesse sido um lapso de formulação. Agora, nesse novo contexto de insistência, cabe afirmar que talvez estejamos diante de um caso de contradição grave de Alexy. Obviamente, entendo que princípios podem ser aplicados "isoladamente",

${ }^{9}$ Cf. Neves (2013, p. 69, nota 94). 
isto é, sem concorrência com outros princípios e sem ser sopesados, o que vale também para Alexy. Minha diferença é que um princípio, enquanto princípio, nunca pode ser razão direta para um juízo concreto de dever-ser. Mesmo quando aplicado "isoladamente" (sem colisão e sem sopesamento com outros princípios ou regras incompletas), ele precisa da intermediação de uma regra completa como razão ou critério definitivo, direto, imediato de uma (norma de) decisão concreta, seja essa regra identificada e selecionada a partir do princípio no material legislativo, nas práticas estabelecidas ou nos precedentes, seja ela inferida do princípio pelo órgão encarregado da interpretação-aplicação jurídico-normativa no caso específico.

Por fim, cabe lembrar que em nenhum momento critiquei a teoria de Alexy "por não aceitar híbridos" nem adicionei "um critério novo" (mediante os híbridos) à teoria de Alexy", como sustenta Silva (2016, p. 105-106). Ofereci um modelo alternativo ao de Alexy, que inclui os híbridos, apontando para certas inconsistências internas em sua teoria e criticando o modelo pretensioso da otimização e temas conexos. Sei que a teoria de Alexy não comporta os híbridos, pois tem um quê de apriorística e, assim, mantém-se imune a argumentos sobre a precariedade das diferenças de conteúdo diante da complexidade do material da experiência, não apresentando suficiente capacidade de aprendizado em face desse material e de argumentos. Daí por que ofereço um modelo mais versátil e capaz de aprendizado e, nesses termos, defendo a superação definitiva (mas não dogmática) do modelo de Alexy.

\section{Por que os híbridos além dos tipos 'regras' e 'princípios'?}

No tópico 4 do seu artigo, Virgílio Afonso da Silva critica-me por introduzir a noção de híbridos e relacionar minha distinção entre regras e princípios ao conceito weberiano de "tipo ideal". Ele parafraseia passagem do meu livro ao afirmar: "Para Weber, tipos ideais são construídos a partir de uma ênfase unilateral em uma ou algumas variáveis do objeto a ser analisado" (SILVA, 2016, p. 104) Nesse particular, ele concorda plenamente como o que afirmei no meu trabalho:

Os tipos ideais, definidos por Weber como "utopias" gnosiológicas, nunca são encontrados em forma pura na realidade social, servindo antes como esquemas de sua interpretação com ênfase unilateral em determinados elementos mais relevantes ao conhecimento que se pretende obter. Na concepção weberiana de tipo ideal, "os elementos considerados não essenciais ou casuais para a constituição da hipótese" não são tomados em conta. [...] Weber deixa claro isso, ao afirmar que esses tipos não se encontram puros na realidade. (NEVES 2013, p. 101-102) $)^{10}$

Também não se pode discordar de sua afirmação do óbvio: “Trata-se, portanto, de uma abstração, de uma construção intelectual que serve como método de análise

${ }^{10}$ Com referência a Weber (1973, p. 190-191, 194, 201-202; 1968, p. 163-164; 1985, p. 124 [trad. bras. 2004, vol. 1, p. 141]). 
sociológica" (SILVA, 2016, p. 104). Entretanto, a partir desses pressupostos corretos, ele admoesta:

Ainda que se aceite que o conceito de tipo ideal tenha alguma relevância na compreensão da distinção normativa entre regras e princípios, com certeza não seria para a configuração de algumas figuras como híbridas. Se é verdade, como afirma Weber, que os tipos ideais são uma utopia e que, "em sua pureza conceitual, essa construção mental não é encontrada em lugar algum", então a conclusão óbvia seria a de que, no mundo real, tudo é híbrido. $[\ldots]$

No caso das regras e princípios, mesmo que se aceitasse que há casos duvidosos, essa dúvida é apenas classificatória e não tem relação com o conceito de tipo ideal. Se se aceita que princípios são normas que estabelecem um dever prima facie e regras são normas que estabelecem um dever definitivo, não parece haver espaço para híbridos. Em outras palavras, pode haver dificuldades, em diversos casos, em se definir se estamos diante de uma regra ou de um princípio, mas isso não decorre da existência de figuras híbridas. Tratase apenas de uma dificuldade classificatória. (SILVA, 2016, p. 104, grifei)

Em primeiro lugar, deve ser enfatizado que não adotei nem apliquei o conceito weberiano de "tipo ideal" estrita e acriticamente. Afasto-me da noção de Weber, ao sustentar que, "enquanto em Weber o conceito de tipo ideal baseia-se na "noção fundamental da teoria do conhecimento moderna que remonta a Kant, de que os conceitos são e apenas podem ser meios mentais para o controle espiritual do empiricamente dado', ou seja, remonta à noção do sujeito transcendental, concebo o 'tipo ideal' como estrutura cognitiva de seleção das ciências sociais em relação à realidade-ambiente, que, diante delas, apresenta-se mais complexa e desestruturada" (NEVES, 2013, p. 102). ${ }^{11}$. Por isso, esclareço:

A distinção kantiana entre o dado e o objeto do sujeito transcendental é aqui transformada na diferença entre dados desordenados do ambiente da ciência e objetos construídos seletiva e ordenadamente pela ciência. (NEVES, 2013, p. 102)

Portanto, apesar de função similar ao do "tipo ideal" weberiano, usei a expressão como categoria dos sistemas científicos ou de outras esferas do conhecimento sistemático e reflexivo, a saber, como algo no plano da comunicação, expresso em proposições ordenadoras do material de conhecimento. Poder-se-ia também dizer que corresponde aproximativamente à "redução" nos termos mais genéricos de Guerreiro

\footnotetext{
${ }^{11}$ Com referência a Weber (1973, p. 208).
} 
Ramos, que, similarmente ao tipo ideal weberiano, "consiste na eliminação de tudo aquilo que, pelo seu caráter acessório e secundário, perturba o esforço de compreensão e a obtenção do essencial de um dado" (RAMOS, 1996, p. 71) ${ }^{12}$. Trata-se, de uma "reconstrução" no sentido de Jürgen Habermas, que ocorre quando "se desmonta uma teoria e a recompõe em uma nova forma, para que melhor se alcance a meta por ela estabelecida" (HABERMAS, 1982, p. 09). Já havia adotado tal formulação de tipo ideal em trabalho anterior, mas me referia, sem grandes problemas, a conceitos tipicamente sociológico, no plano das expectativas cognitivas (NEVES, 1992, p. 110-111). Admito que a situação se torna mais delicada quando se aplica em relação à ordenação de expectativas normativas, ou seja, ao âmbito do conhecimento referente a normas. É verdade que Weber admite, como reconhece Silva (2016, p. 104 e 115, nota 31), a aplicação dos tipos ideais para normas jurídicas, mas observa essa questão em uma perspectiva sociológica:

O cosmo das normas jurídicas é naturalmente, ao mesmo tempo, claramente determinável em termos conceituais e (em sentido jurídico!) válido para a realidade histórica. Mas é com a sua significação prática que o trabalho da ciência social no nosso sentido tem a ver. Muito frequentemente, porém, essa significação só pode ser levada claramente à consciência mediante a referência do dado empírico a um caso-limite ideal. (WEBER, 1973, p. 195)

O que eu propus foi a extensão de minha tipificação ideal das normas além de uma perspectiva sociológica ou científico-social, para admiti-la do ponto de vista da reflexão da teoria do direito. É claro que se trata de uma ousadia, de algo teoricamente ambicioso, que pode encontrar reações e críticas abalizadas. Mas esse não é o caso das censuras de Silva, que antes me parecem frágeis e, potencialmente, estagnantes do pensar autônomo. Vejamos a seguir.

Em primeiro lugar, não parto simplesmente do conceito semântico de norma, nos termos de Alexy (1986, p. $42-47$ [trad. bras. 2008, p. 53-58]), mas antes bem formulado por Von Wright (1963, p. 93 ss), tal como o faz Silva. Esse conceito, com base na lógica, é importante para o nível jurídico-doutrinário ou jurídico-dogmático e para a prática jurídica. Mas ele permanece em nível superficial. Não me parece que a teoria do direito deva limitar-se a ele. Pressuponho o conceito de norma no sentido da teoria sistêmica, isto é, como expectativas normativas socialmente estabilizadas. Portanto, não concebo ser e dever-ser como dois mundos, mas sim como duas perspectivas de construção da realidade. Apesar de minhas restrições ao modelo de Niklas Luhmann, assumo o seu argumento a esse respeito:

Embora orientado em termos contrafactuais, o sentido do dever-ser não é menos factual do que o sentido do ser. Toda expectativa é factual, seja na sua satisfação ou não satisfação. O factual abrange o normativo.

12 Advirta-se, porém, que a "redução sociológica" em Ramos (1996, p. 71-74) não se limita à "redução" em "seu sentido mais genérico" aqui citado, tendo outros elementos definidores. 
A contraposição usual entre o factual e o normativo deve ser, portanto, abandonada. [...] $\mathrm{O}$ normativo encontra o seu adequado contraste não no factual, mas sim no cognitivo. É possível optar com sentido apenas entre essas duas posturas relativas ao processamento de desapontamentos, não entre o factual e o normativo.

Além disso, é importante não inflar imediatamente essa diferenciação entre expectativas cognitivas e normativas no sentido da antiga oposição objetiva ou lógica entre ser e dever-ser, mas sim, em primeiro lugar, compreender a função da própria diferenciação. Ela coloca à disposição duas estratégias diferentes, mas mesmo assim funcionalmente equivalentes, para a sequência da vida após desapontamentos. Pode-se aprender ou não. Ambas as possibilidades podem ajudar na superação de situações de desapontamentos, preenchendo assim, apesar das orientações contrárias, a mesma função. O sucesso está baseado no fato de que a mesma função é preenchida não só por comportamentos "semelhantes", mas por comportamentos diretamente opostos. Isso facilita o encontro de uma solução para qualquer caso de desapontamento. Dependendo da relevância da expectativa e das chances de realizá-la, pode-se optar por sua sustentação ou pela renúncia a ela. (LUHMANN, 1987, p. 43-44)

Embora contrafactual na sua referência à realidade, as normas enquanto expectativas normativas condensadas e estabilizadas socialmente estão no plano do real e dos fatos e, portanto, uma teoria do direito consequente, que não seja puramente formalista, não pode dar as costas aos problemas daí decorrentes. Para ser norma, não basta que haja um texto e um significado prescritivo. É fundamental que haja expectativas estabilizadas nos respectivos contextos sociais. Isso permite que se reflita também sobre situações em que textos com significado normativo não são expressões de norma. Um exemplo é dado em recente trabalho por Christoph Möllers (2015, p. 287), referindo-se ao artigo 67 da Constituição da Coréia do Norte, concernente à liberdade de expressão que, apesar de ter a forma linguística de uma disposição normativa e, portanto, de conter um significado normativo, não é norma, constituindo, no máximo, um artefato simbólico da política, sem nenhuma força normativa. Essa não é uma questão que interessa apenas à sociologia, orientada primariamente para estruturas cognitivas, mas também à teoria do direito e à teoria jurídico-constitucional, orientadas primariamente para estruturas normativas. Nesse sentido, considero que princípios e regras jurídicas ou constitucionais são dois conceitos típicos mediante os quais se seleciona como as expectativas normativas condensadas como normas dirigem-se contrafactualmente ao comportamento humano e à ação social. Daí por que considero que são dois tipos ideais de normas na perspectiva normativa da teoria do direito.

Silva, porém, sustenta que, "ainda que se aceite que o conceito de tipo ideal tenha alguma relevância na compreensão da distinção normativa entre regras e princípios, com certeza não seria para a configuração de algumas figuras como híbridas", acrescentando que se trataria apenas de "dificuldade classificatória". Virgílio sugere, 
assim, que teria aplicado erroneamente a categoria weberiana.

Não cabendo aqui insistir que não apliquei simplesmente o conceito de Weber, mas ofereci uma reconstrução conceitual, cumpre, sim, observar primeiramente que Silva parece não ter compreendido a função do tipo ideal na obra de Weber. O tipo ideal tem uma função de ordenar o material do conhecimento em Weber. Ao contrário do que insinua Silva, os "tipos ideais" implicam uma forma de classificação do material do conhecimento. Não são "puros conceitos classificatórios" nos termos da "simples" determinação do gênero próximo e da diferença específica com pretensão de esgotar o material empírico no sentido de uma taxinomia esgotante, pois, para Weber (1973, p. 194, 201-202, "tal forma de verificação do significado da palavra existe apenas no solo das disciplinas dogmáticas que trabalham com silogismos", sendo um "disparate" em relação à realidade histórica e social (WEBER, 1973, p. 194). Mas os "tipos ideais" pertencem funcionalmente à classificação "orientadora", tal como Weber expressa em relação a conceitos referentes a tipos de estados, ao afirmar que "esses conceitos típicoideais servem apenas como orientações para classificar os estados", mas deixando claro que a maioria dos estados afasta-se, mais ou menos, dessa "simples classificação" (WEBER, 1968, p. 158). Sendo uma classificação orientadora, ela tem os seus limites.

Portanto, nem toda a experiência, instituição, estrutura, organização ou processo social aloca-se por aproximação comparativa em um tipo ideal. Há casos em que a situação não se enquadra primariamente em nenhum dos tipos específicos, constituindo mistos, especialmente nas fases históricas de transição. Assim, por exemplo, ao falar do conceito de cidade, Weber afirma: "é patente o contraste, particularmente em relação às condições asiáticas, das cidades do Ocidente medieval, e entre estas especialmente as cidades ao norte dos Alpes, onde se desenvolveram com pureza típica ideal" (Weber, 1985, p. 741 [trad. bras. 2004, vol. 2, p. 425]).

É claro que, nesse trecho poder-se-ia vislumbrar uma contradição na obra de Weber (1985, p. 124 [trad. bras. 2004, vol. 1, p. 141]), como já se apontou, pois se o tipo ideal nunca se realiza "puramente" na realidade, como poderia um tipo ideal realizar-se na "sua pureza" em uma experiência histórica? Mas me parece caber interpretar Weber de outra maneira, no sentido de que o tipo ideal "cidade" ter-se-ia realizado de forma primária e genuína no ocidente medieval, considerando que na Ásia teria havido formas de transição, mas ainda não se teria formado tipicamente cidades. Situação atípica, em que a experiência não se aproxima predominantemente de nenhum dos tipos ideais envolvidos, apresenta-se também quando, no contexto da classificação das três formas de dominação legítima, a saber, tradicional, carismática e legal-racional, Weber trata da "rotinização [cotidianização] do carisma", considerando, porém, que, "em sua forma genuína, a dominação carismática é de caráter especificamente extracotidiano" (WEBER, 1985, p. 142-143 [trad. bras. 2004, vol. 1, p. 161-162]). Sendo a "veneração extracotidiana" característica típica e própria da dominação carismática e a "crença cotidiana" típica e própria da dominação tradicional (WEBER, 1985, p. 124 [trad. bras. 2004, vol. 1, p. 141]), parece-me que não se pode negar que a "rotinização [cotidianização] do carisma" constitui uma experiência atípica, um híbrido de dominação tradicional e dominação carismática. Weber reconhece expressamente, com frequência, a existência de "formas mistas" e de "misturas". Assim, por exemplo, ao tratar de dominação burocrática, afirma que "seus tipos 'puros' somente devem ser considerados casos-limite particularmente valiosos e indispensáveis para a análise, 
entre os quais se move e continua se movendo a realidade histórica, que quase sempre apresenta formas mistas" (WEBER, 1985, p. 578 [trad. bras. 2004, vol. 2, p. 233], grifei).

Weber fala até mesmo de "tipos mistos", como ocorre em relação à cidade: "Parece óbvio que quase todas as cidades empíricas representam tipos mistos e, por isso, somente podem ser classificadas segundo seus componentes econômicos predominantes" (WEBER, 1985, p. 730 [trad. bras. 2004, vol. 2, p. 412], grifei) ${ }^{13}$. Em vários contextos se pode falar de situações atípicas, embora os conceitos típico-ideais weberianos como orientadores da classificação permaneçam intocáveis. Por exemplo, há experiências históricas em que há misto de capitalismo e feudalismo, sendo impossível afirmar se a experiência aproxima-se mais do tipo ideal de capitalismo ou de feudalismo. No que concerne ao exemplo de Silva sobre a monarquia sueca, porém, é claro que se trata de uma monarquia típica, pois se enquadraria primariamente no respectivo tipo ideal. Entretanto, se tomarmos o parlamentarismo e o presidencialismo como dois tipos ideais concorrentes, poderíamos dizer, sem dúvida, que o atual sistema de governo francês não é tipicamente nem parlamentarismo nem presidencialismo, ao contrário dos Estados Unidos e do Brasil, que se enquadram tipicamente, em graus diversos, no presidencialismo, por um lado, e da Inglaterra e da Índia, que se enquadram tipicamente, em graus diversos, no parlamentarismo, por outro lado. A esse respeito, é interessante notar que, ao tratar dos tipos de dominação, Weber (1985, p. 823 [trad. bras. 2004, vol. 2, p. 526-527]) sustentava que a análise detalhada das "formas intermédias e combinações altamente complicadas desses tipos puros [...] faz parte dos problemas da 'teoria geral do Estado'".

$\mathrm{Na}$ minha reconstrução teórica, considerei que há dois conceitos "típico-ideais" de normas jurídicas, com função de classificação orientadora: princípios e regras. $\mathrm{O}$ material normativo poderá enquadrar-se primariamente em um desses dois tipos. Então, teremos regras típicas e princípios típicos no plano normativo. Caso a norma não se aproxime primariamente de nenhum desses tipos ideais, ela é uma norma atípica, não constituindo um novo tipo ideal nem correspondendo primariamente a um determinado tipo. Sem dúvida, isso pode ter algo a ver com dificuldade classificatória, mas também está associado à estruturação ambivalente das expectativas normativas que se condensam na respectiva norma.

Além da infundada censura à minha aproximação com a noção weberiana de tipo ideal, Silva sustenta que os híbridos decorrem do fato de que eu injustificadamente misturo dois critérios de distinção entre princípio e regras, discorrendo nos seguintes termos:

\begin{abstract}
A impressão de que se trata de um híbrido decorre da atribuição da característica "ser aplicado diretamente à solução de um caso" apenas às regras, algo que Marcelo Neves faz, a meu ver, sem justificativa plausível. Mais do que isso: ao misturar dois critérios para definir o que distingue uma regra de um princípio, cria-se automaticamente a figura do híbrido. Se se define princípio como uma norma passível de
\end{abstract}

${ }^{13}$ Cf. também WEBER (1985, p. 13, 20, 153-154, 550, 823 [trad. bras. 2004, vol. 1, p. 16, 23, 173-174, vol. 2, p. 198, 526-527]). 
sopesamento e, ao mesmo tempo, como uma norma que não pode servir diretamente à solução do caso, cria-se, por meio da própria definição, a possibilidade dos híbridos: quando a norma é passível de sopesamento e, ao mesmo tempo, serve para a solução direta de um caso, ela não se enquadra perfeitamente nem na categoria dos princípios (justamente porque soluciona diretamente o caso) nem na categoria das regras (porque é sopesável). O surgimento do híbrido, aqui, não tem nenhuma relação com o conceito de tipos ideais, mas com uma mistura indevida de critérios distintivos. (SILVA, 2016, p. 104-105)

Mas, a essa altura, há uma falta de compreensão e mesmo uma deformação e inversão da minha teoria com a de Alexy. Quem utiliza dois critérios de maneira confusa é Alexy. Por um lado, ele distingue entre princípios e regras considerando que os primeiros são razões prima facie (não podendo ser razões definitivas mesmo quando aplicados "isoladamente") e que as regras atuam como razões definitivas de juízos de dever-ser. Por outro lado, ele afirma que a distinção reside em que os princípios (mesmo isolados) são mandamentos de otimização, enquanto as regras distinguem-se por serem satisfeitas ou não satisfeitas (apesar dos esforços de Alexy (1986, p. 75 ss [trad. bras. 2008, p. $90 \mathrm{ss}$ ] $)^{14}$, não vejo aqui uma diferença prática relevante em relação ao "tudo-ou-nada" de Dworkin). É claro que ser razão prima facie não implica necessariamente que seja mandamento de otimização. Também ser razão definitiva não é o mesmo critério que "ser satisfeita ou não satisfeita". Nós temos, nesse caso, sim, dois critérios misturados. Além disso, Alexy (1986, p. 121 [trad. bras. 2008, p. 140]) dá deslizes homéricos na sua pretensão de apresentar uma classificação esgotante das normas jurídicas existentes (excluídas evidentemente as chamadas "normas individuais"). Um deles apresenta-se, como já tratei acima (p. 279-280), quando ele afirma que há "regras incompletas", que são suscetíveis de sopesamento, de tal maneira que "a decisão constitucional pressupõe um recurso ao nível dos princípios, com todas as incertezas que estão a ele vinculadas" (seriam elas híbridos?!). Um outro vem à luz quando ele aponta para caso em que os princípios prevaleceriam sobre uma regra no mesmo grau de hierarquia normativa na dinâmica jurídica (ALEXY, 1986, 122 [trad. bras. 2008, p. 140]). Mas será que a regra, aqui, atuaria realmente como razão definitiva e seria apenas satisfeita ou não satisfeita, e o princípio seria apenas razão prima facie, não atuando como razão definitiva que afasta a regra no caso? (Ou estaríamos diante de híbridos?).

Ao contrário, eu proponho uma distinção típico-ideal inequívoca entre regras e princípios do ponto de vista funcional-estrutural: princípios são normas que atuam apenas em caráter reflexivo com relação às regras e, portanto, são apenas razões prima facie em relação à decisão do caso concreto, ou seja, ao juízo concreto de dever-ser, estando estruturalmente no plano da observação de segunda ordem em relação ao julgamento; regras (inclusive metarregras) podem atuar como razões definitivas - isto é, diretas, imediatas - de um juízo concreto de dever-ser, no final do processo de

\footnotetext{
${ }^{14}$ Cf. Neves (2013, p. 61, 63 ss).
} 
concretização, encontrando-se estruturalmente, então, no plano de observação de primeira ordem do julgamento (NEVES, 2013, p. 98-101, 120 ss). Como decorrência funcional necessária dessa classificação, sustentei que as regras servem primariamente ao fechamento e os princípios primariamente à adequação social do direito (NEVES, 2013, p. XVIII-XIX, 127-129, 227). O sopesamento não é critério de distinção para mim. Tanto princípios quanto regras são sopesáveis no meu modelo, como já afirmado acima. Insista-se, porém, que, seguido de referência a casos, consta claramente do meu trabalho que, "embora a regra na sua formulação definitiva e completa, como um fundamento de uma norma de decisão, só pode ser aplicada binariamente, ela é prima facie suscetível de comportar uma dimensão de peso e, portanto, de submeter-se a critérios de ponderação em um caso concreto" (NEVES, 2013, p. 77). É uma questão puramente quantitativa, sem relevância na minha classificação. Excluídos os casos rotineiros, nos quais, para mim, a distinção entre regras e princípio é irrelevante, não se pode evitar que haja sopesamento de regras com princípios, e mesmo entre regras, antes do fechamento do processo concretizador, quando ela é aplicada por subsunção. Só, então, a regra deixa de ser "incompleta", passando a atuar como razão definitiva do julgamento. E, insista-se, ser razão definitiva é ser razão direta ou imediata em minha teoria. Conforme meu entendimento, mesmo quando "tomado isoladamente" (a rigor: sem precisar de sopesamento com outro princípio ou com uma regra "incompleta"), o princípio não se torna razão definitiva do caso a decidir e, portanto, não pode ser aplicado como razão direta, imediata do julgamento do caso concreto, precisando que se identifique $(\mathrm{m}) \mathrm{a}(\mathrm{s})$ regra(s) a partir do princípio ou se infira(m) dele a(s) regra(s) que servirá(ão) de razão(ões) direta(s), definitiva(s), imediata(s) da decisão concreta. Portanto, como já adiantado, parece-me que Alexy entra em grave contradição nesse particular: por um lado, ele afirma que "sempre que um princípio for, em última análise, uma razão decisiva para um juízo concreto de dever-ser, então, esse princípio é o fundamento de uma regra, que representa uma razão definitiva para esse juízo concreto", sustenta, ademais, que, "em si mesmos, princípios nunca são razões definitivas", pois, "ao contrário" das regras, "são sempre razões prima facie", e, por fim, defende que, "isoladamente considerados, eles estabelecem apenas direitos prima facie"; por outro lado, declara que os princípios podem ser "razões diretas para decisões concretas". Mesmo quando não precisam ser sopesados (sejam aplicados "isoladamente"), os princípios precisam ser intermediados por uma regra como razão definitiva do juízo concreto de dever-ser. Isso vale para minha teoria. E deveria valer para a de Alexy, se ela fosse consistente a esse respeito.

Concedo que a aproximação ao modelo weberiano de tipos ideal pode ser a parte controversa e discutível do meu trabalho, digna de questionamento. A crítica de Silva, contudo, não me parece suficientemente sofisticada para convencer-me de uma revisão do meu trabalho nesse particular. De certa maneira, trata-se de experimentalismo em sentido similar ao de John Dewey (1963, p. 273; 1946, p. 202-203), ou seja, da tentativa de testar a validade de uma sugestão, sem crença "absolutista" e com prontidão e flexibilidade para revisão. Mas, na verdade, fiz essa aproximação por entender que, nas ciências sociais e outras formas de conhecimento reflexivo e sistemático no âmbito das chamadas "ciências humanas", toda pretensão de conceituação e classificação gerais sempre tem algo de típico-ideal no sentido análogo 
ao de Weber, pois não esgota o material "fluido" do conhecimento. Dessa maneira, não adotei um modelo taxinômico clássico conforme gênero e espécie, com pretensão lógico-silogística esgotante do real, mas antes admiti os limites de minha classificação "orientadora" em face da "fluidez" (WEBER, 1985, p. 578 [trad. bras. 2004, vol. 2, p. 233]) do material normativo, concedendo a existência de híbridos, mas isso não implica fragilidade nem imprecisão conceitual ou classificatória.

\title{
V. AS COLISÕES INTRAPRINCÍPIOS
}

Virgílio Afonso da Silva também censura, no tópico 6 do seu artigo, a minha abordagem das colisões intraprincípios, na medida que esta serve para apontar limites da teoria de Robert Alexy. Silva afirma, em comentário brevíssimo a esse respeito:

\begin{abstract}
Não me parece haver diferença entre uma colisão entre dois princípios distintos e uma colisão que envolva o mesmo princípio. Especialmente para a definição sobre o quão ilimitado os princípios são prima facie, essa é uma distinção que não me parece relevante. E os exemplos usados por Neves não são suficientes para demonstrar o contrário. Especialmente aqueles exemplos relacionados a choques culturais como os distintos valores atribuídos ao direito à vida na cultura ocidental e em algumas culturas indígenas - não parecem ter ligação direta com a distinção teórica entre princípios e regras. Esses choques - e todos as suas consequências - ocorrem não importa que teoria sobre normas jurídicas seja adotada. (SILVA, 2016, p. 106)
\end{abstract}

Também nesse particular, parece-me frouxa a reserva apresentada por Silva. Quando considerei as colisões intraprincípios, afastei-me criticamente de uma noção clássica de direito subjetivo, adotada por Alexy, que o leva a admitir que os direitos fundados em princípios são prima facie "ilimitados", especialmente o direito geral de liberdade (ALEXY, 1986, p. 342 ss [trad. bras. 2008, p. 377 ss]; NEVES, 2013, 161 ss). Partindo de uma concepção transsubjetiva dos direitos, não apenas intersubjetiva, nos termos da teoria dos sistemas (LADEUR, 2014; FISCHER-LESCANO, 2013, p. 17 ss), afirmei que todo direito fundamental de uma pessoa é limitado pelo idêntico direito fundamental de outra pessoa. Daí decorre que nenhum direito é prima facie ilimitado e, portanto, pode haver sopesamento no âmbito do mesmo princípio quando diversas pessoas ou grupos, em conflito, afirmam o direito fundado nesse princípio, ou quando há compreensões diversas desse princípio em diferentes esferas sociais. E isso vale também em relação ao direito geral de liberdade. Caso Alexy assumisse o meu argumento, ele não poderia falar mais de direitos ilimitados prima facie com base em princípios, nem defender a chamada "teoria externa" nos termos postos por ele. Apontei, então, que Alexy se filia à noção hobbesiana de direito ou liberdade: "O direito consiste na liberdade de fazer ou de omitir [...]. Naturalmente, todo homem tem direito a todas as coisas, inclusive os corpos dos outros" (Hobbes, 1991 [1651], p. 91 [64]). Estaria em posição contrária à de Locke, conforme o qual a liberdade do estado de natureza, ao contrário da "licenciosidade", importa que nenhum homem "deve

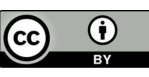


prejudicar a outrem na vida, na saúde, na liberdade ou nas posses" (LOCKE, 1980 [1690], p. 9) ${ }^{15}$, de tal modo que o direito geral de liberdade seria limitado prima facie, inclusive por outros direitos. Apontei que, em obra filosófica, Alexy admite que "nenhum direito à liberdade é ilimitado", "ao menos, no ponto em que vai de encontro à liberdade dos outros" (ALEXY, 1998, p. 253; NEVES, 2013, p. 161, nota 168). Mas nada disso aparece quando ele trata de direitos ilimitados prima facie, o que leva a crer que sua referência filosófica não diz respeito a essa situação dos direitos fundados em princípios constitucionais, mas ao caráter definitivo do direito à liberdade.

Alexy parte dos princípios como grandezas a serem otimizadas, suscetíveis de sopesamento com outros princípios conforme uma "fórmula do peso" (ALEXY, 2003), em que as variáveis se referem aos diferentes princípios ou direitos neles fundados. Ele não poderia aceitar a ideia de direito limitado prima facie de alter e ego com base em um mesmo princípio, pois isso levaria a sua arquitetura conceitual ao colapso. Além de tudo, ao banalizar o meu argumento sobre colisões intraprincípios, dizendo que eles "ocorrem não importa que teoria sobre normas jurídicas seja adotada", Silva não indica um exemplo em que Alexy, ele ou qualquer discípulo de Alexy tenha tratado ou se ocupado de um caso de colisão hard no âmbito do mesmo princípio e como se desenvolveu o respectivo sopesamento. Os profetas também têm seus limites!

\section{POR QUE UM SOPESAMENTO COMPARATIVO? A PRECARIEDADE DA RAZÃO}

No que concerne ao cerne de minha crítica ao modelo de Robert Alexy, a saber, minha rejeição à relação indissociável entre otimização e sopesamento entre princípios, que supõe a noção de princípios como mandamentos de otimização, Virgílio Afonso da Silva, no tópico 9, censura-me e defende mais uma vez o modelo do seu mestre. Em primeiro lugar, ele afirma que, na medida em que eu parto do "pressuposto de que a ponderação é inafastável", meu "modelo em grande parte coincide com o modelo de Alexy, que vê na ponderação um elemento central" ( SILVA, 2016, p. 108). Mas evidentemente, para mim, sopesamento não é um critério classificatório de normas (regras podem ser sopesadas) e é um traço banal de todo comportamento humano ou agir social. Mesmo os primatas não humanos sopesam ${ }^{16}$. Portanto, não há nenhuma coincidência do meu modelo com o de Alexy nesse ponto. Virgílio vai além e diz que a tentativa de se afastar de Alexy, então, "baseia-se na estratégia de aceitar a ponderação, mas sem aceitar a otimização" (SILVA, 2016, p. 108). Sim, mas se acrescente que, a rigor, diferentemente de Alexy, tanto admito sopesamento entre regras (sem que seja necessário um "recurso ao nível dos princípios") quanto não vinculo o sopesamento à otimização e, portanto, também não adoto a ideia de que princípios sejam mandamentos de otimização.

\footnotetext{
${ }^{15}$ Cf. Neves (2013, p. 161, nota 167).

${ }^{16}$ Cf. Boehm (1999, p. 163 ss) e Almeida (2014, p. 35-37).
} 


\title{
1. Afinidade entre a "melhor resposta" (Dworkin) e a otimização (Alexy)
}

Na sua crítica, no tópico 9.1, Silva inicia com uma astuta deformação de um dos meus argumentos, que não é fundamental para minha crítica ao modelo de otimização. Reverberando argumentos de Alexy, ele afirma:

\begin{abstract}
Uma das principais razões para a afirmação acima é a aproximação que Neves faz entre otimização, no sentido de Alexy, e a noção de única resposta correta, no sentido de Dworkin. Não é o caso de analisar aqui a fundo o debate sobre a ideia dworkiniana de única resposta correta. Parece-me ser suficiente: (1) remeter à objeção que o próprio Alexy faz a tese da única resposta, a qual, segundo ele, é "condenada ao fracasso" e (2) constatar que, se otimizar fosse 'buscar a única resposta correta', então o legislador não teria, nunca, liberdade para legislar, já que essa liberdade está baseada diretamente da existência de diferentes respostas (corretas) a um mesmo problema. (SILVA, 2016, p. 109, grifei)
\end{abstract}

Em primeiro lugar, cumpre observar que, em nenhum momento de minha obra afirmei que "otimizar fosse "buscar a única decisão correta'". Apenas aludi a uma aproximação dos modelos, entendendo que o modelo contrafactual de Dworkin (eu diria antes "maximizante"), enquanto orientado, em sua formulação inicial, para uma "única resposta correta" (Dworkin, 1978, p. 279 [trad. bras. 2002, p. 249]) e, principalmente na formulação posterior, para a "melhor resposta" (Dworkin, 1986, p. 239 [trad. bras. 2003, p. 286-287]), tem uma certa afinidade com o modelo normativo de otimização de Alexy (um campo ótimo de decisões corretas). Assim, embora entenda que os dois modelos são fantasiosos, não levando em conta a complexidade do social e a precariedade da razão jurídica, sempre fui cauteloso para não confundir as duas concepções. Dessa maneira, afirmei em meu trabalho apenas o seguinte: "É verdade que o conceito de Alexy não é empírico, mas sim contrafactual. Aponta para um dever-ser ideal. Nesse sentido, ele se assemelha à ideia de uma única decisão correta ou do melhor julgamento, defendida por Dworkin" (NEVES, 2013, p. 82).

Ao afirmar que a concepção de Alexy "se aproxima da noção de uma única decisão correta ou da melhor decisão, no sentido de Dworkin" (NEVES, 2013, p. 141), poderia ter acrescentado que o modelo otimizante de Alexy aproxima-se ainda mais de Dworkin na área cinzenta da busca da "melhor resposta", conforme a formulação posterior deste autor. Entretanto, aproximação ou semelhança não é o mesmo que identidade conceitual.

Mas é inegável a afinidade entre os dois modelos. Otimização exige que a alternativa escolhida seja tão boa quanto as outras: “De acordo com a teoria da otimização como escolha justificada, a escolha de uma alternativa é justificada apenas se a alternativa é, no mínimo, tão boa como qualquer outra alternativa" (HSIEH, 2016, tópico 4.1).

Essa definição corresponde às palavras de Ruth Chang (2002b, p. 46) quando esclarece que a otimização é "a visão de que o que justifica a escolha de uma alternativa em face de outra é o fato de que a alternativa escolhida é, no mínimo, tão boa quanto

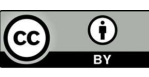


a outra com respeito ao que importa na escolha". Nesse sentido, mesmo que haja um campo de escolha discricionária de opções na otimização, a opção assumida não poderá ser menos boa do que nenhuma outra que esteja nesse campo, o que torna a otimização mais próxima da ideia de busca da "melhor resposta" do que da ideia de uma "única reposta correta", mas, sem dúvida há afinidade com ambas, ao menos se "uma ponderação otimizante se aplica quando em ambos os lados da colisão existem fins obrigatórios que devem ser cumpridos pelo ponderador da melhor maneira possível" (SIECKMANN, 2006, p. 131).

Mas essa afinidade entre a busca hercúlea da "melhor resposta" e a busca de uma decisão que seja tão boa quanto as outras alternativas na zona do ótimo ainda se justifica pela própria dubiedade de Alexy. Embora sustente que princípios são mandamentos de otimização, ele afirma, em uma passagem, que, quando se trata das submáximas da proporcionalidade concernente à adequação e à necessidade, estaríamos diante da exigência de maximização.

Se se deixa de lado um dos princípios colidentes, a referência às possibilidades jurídicas perde o seu significado. De mandamento de otimização, o princípio seria transformado em mandamento de maximização relativo apenas às possiblidades fáticas. Isso conduz a ideia geral de que os princípios se isoladamente considerados - isso é, independentemente de sua relação com outros princípios -, têm natureza de mandamento de maximização. (ALEXY, 1986, p. 80, nota 37 [trad. bras. 2008, p. 95, nota 37])

Mas então, nesses casos, os princípios seriam mandamentos de maximização e, no da ponderação, seriam mandamentos de otimização? Admitida essa inferência natural, a teoria dos princípios como mandamentos de otimização ou a serem otimizados estaria arruinada. A resposta de Alexy a esse respeito é confusa e incapaz de convencer:

Em virtude disso, alguém poderia pensar em definir os princípios como mandamento de maximização, ao invés de mandamento de otimização. Mas essa definição não contemplaria a relação constitutiva que os princípios têm com outros princípios. Seria, então, necessário ou expandi-la, por meio da edição de uma regra de otimização ao mandamento de maximização, ou suplementá-la, por meio de uma definição como mandamentos de optimização que abarcasse a conexão entre os princípios. Diante disso, a definição geral aqui acolhida princípios como mandamento de otimização - tem a vantagem da simplicidade. Além disso, ela não exclui, se for conveniente, a adoção de um ponto de vista no qual princípios sejam considerados em si mesmos ou de forma isolada, o que ao longo do texto ocorrerá com frequência. (ALEXY, 1986, p. 80-81, nota 37 [trad. bras. 2008, p. 95-96, nota 37] 
Mas se uma norma se define como mandamento de otimização, não se poderia atribui-lhe a função de maximizar. Tal inconsistência torna ainda mais infundada a censura de Silva à minha aproximação da teoria de Alexy ao modelo da "melhor resposta", tal como proposto por Dworkin. Se nenhuma outra na zona do ótimo pode ser melhor, a alternativa escolhida é também, de certa maneira, "a melhor", entre outras.

\section{Precedentes e sopesamento ad hoc}

No tópico 9.3, em breve passagem, Virgílio Afonso da Silva censura-me por supostamente "ignorar o valor dos precedentes na teoria dos princípios" e por ter afirmado que "a ponderação está ligada a uma racionalidade ad hoc, 'sem perspectiva de longo prazo"", de tal maneira que os argumentos "tendem a limitar-se ao caso concreto" (SILVA, 2016, p. 110). Aponta, então, para a "reiterada menção aos precedentes por toda obra de Alexy" e alega que já teria afirmado que a "insegurança jurídica está intimamente ligada à ideia de decisão ad hoc, independentemente do método de interpretação e aplicação do direito e da teoria que subjaz a esse método" (SILVA, 2016, p. 110). Nesse contexto, ao usar o termo "ad hoc", as citações referem-se a passagens em que estou a discutir a doutrina e a prática jurídico-constitucionais brasileiras, não a teoria de Alexy, o que demonstra a dificuldade de Silva em distinguir os níveis de argumentação em meu trabalho. Entretanto, é verdade que, em outra passagem do livro a que Silva alude no tópico 9.2 do seu artigo (SILVA, 2016, p. 110), refiro-me, com menção a Ladeur (2007, p. 367), à "concentração nos efeitos de curto prazo" no "paradigma da ponderação otimizante" (NEVES, 2013, p. 148) ${ }^{17}$. Com essa ressalva, seguem os meus comentários.

As afirmações peremptórias de Silva simplificam o meu argumento, mas não convencem. É claro que qualquer teoria minimamente consequente tem que enfrentar os precedentes, pois neles há várias regras e também princípios atribuídos indiretamente ao texto constitucional. Às vezes, o sopesamento deve recair sobre princípios atribuídos ao texto constitucional pela jurisprudência. Entretanto, mencionar frequentemente os precedentes não significa processá-los adequada e consistentemente. O Supremo Tribunal Federal e alguns doutrinadores brasileiros fazem numerosas menções a precedentes, mas, frequentemente, elas são desastradas (e eu estava ocupado deles a essa altura do trabalho). E uma afirmação eventual de que a decisão ad hoc relaciona-se com insegurança jurídica não é nenhuma comprovação de que o modelo teórico não tenda ao sopesamento ad hoc. Além disso, afirmar que a existência de decisão ad hoc "independente do método de interpretação e aplicação do direito e da teoria que subjaz a esse método" parece-me não só ser problemático por separar radicalmente teoria e práxis, mas também constituir uma forma de álibi da teoria, que transfere os problemas para o "controle social" apenas. Mas não houve uma teoria e um método de interpretação que justificou o decisionismo ad hoc no período do nacional socialismo? Teorias, especialmente no campo do normativo, não são totalmente isentas em face da respectiva prática.

${ }^{17}$ Cf. também Neves (2013, p. 201). 
Acrescento agora: a pretensão otimizante de Alexy, vinculada a cada contexto, tende a um sopesamento ad hoc, no mesmo sentido que sustenta Bernstorff (2010, p. 12, $70,362,371 ; 2014,76$ ss). ${ }^{18}$ Por quê? O próprio Alexy sublinha que o sopesamento é algo estrito ao caso, contextual:

Na verdade, o que ocorre é que um dos princípios tem precedência em face do outro sob determinadas condições. Sob outras condições a questão pode ser resolvida de forma oposta. Isso é o que ser quer dizer quando se afirma que, nos casos concretos, os princípios têm pesos diferentes e que os princípios com o maior peso têm precedência. (ALEXY, 1986, p.79 [trad. bras. 2008, p. 93-94])

Tomada isoladamente, essa tese não seria problemática. Entretanto, em um modelo de otimização, ela se torna discutível. As condições variam incontrolavelmente. Se formos, em todo caso, considerar todas as condições no afã otimizador, a cada caso a história começaria e encerrar-se-ia novamente. Só quando se assume que certas condições concretas são excluídas, outras já foram tipificadas seletivamente em precedentes e poderão ser tipificadas seletivamente para o futuro, é que se pode superar a tendência de argumentos ou ponderações ad hoc, sem nenhum caráter definitório. Mas isso exigiria um sopesamento sem a pretensão otimizante, apenas comparativo, conforme uma racionalidade precária.

A questão não é que Alexy não mencione os precedentes, mas sim que o seu modelo de sopesamento não oferece uma perspectiva de longo alcance e que seja apta a processar satisfatoriamente os precedentes, nos termos que poderia advir de um sopesamento definitório. Observe-se que grande parte de suas menções aos precedentes é apenas para afirmar o seu modelo de otimização como algo que reconstrói racionalmente a jurisprudência do Tribunal Constitucional Federal da Alemanha à época, não para enfatizar o valor dos precedentes para o processo de sopesamento. Os casos, em sua identidade concreta, são encapsulados na "fórmula do peso" e delas se tornam refém.

Portanto, o modelo de Alexy enfatiza a dimensão da variedade, mas não da redundância. A redundância fica fragilizada se há uma crença contrafactual na otimização em cada caso, em todo e qualquer contexto. Sim, não se oferece critérios satisfatórios para reduzir "o 'valor surpresa' das decisões de futuros casos"19. O presente quase se absolutiza na busca do ponto ótimo contextual, quase sem passado e quase sem futuro. Tal modelo só funcionaria se fossem "consideradas todas as coisas" por um sujeito privilegiado do sopesamento, observador perfeito de todas as perspectivas em torno do caso e capaz de aplicar corretamente a "fórmula do peso", preenchendo-a na justa medida. Porém, os limites do conhecimento do intérpreteaplicador do direito e da Constituição, envolvido em contexto processual para o qual conflui uma pluralidade de expectativas, exige soluções que levem em conta a

${ }^{18}$ Cf. Neves (2013, p. 200-201).

${ }^{19}$ Citando-me, Silva (2016, p. 110). Cf. Neves (2013, p. 125-126, 152, 196, 198-199, 227). 
redundância e admita revisões de soluções precárias no futuro. Uma certa suspensão da temporalidade por uma fórmula sintática é o que se observa na teoria de Alexy. A temporalidade do direito não é devidamente considerada em seu modelo de sopesamento otimizante em cada caso. Silva não acrescenta nada em seu breve comentário a respeito, apenas insiste na menção aos precedentes por Alexy e em uma afirmação eventual de sua própria autoria. Faltaram os argumentos.

\section{Sopesamento comparativo e otimização}

Nos tópicos 9.2 e 9.4, Virgílio Afonso da Silva critica minha admissão de um sopesamento comparativo como alternativa à otimização. Incialmente, ele afirma:

Ao aceitar a ponderação como inafastável e, ao mesmo tempo, rejeitar a ideia de otimização (ainda que, a meu ver, por razões equivocadas, já que baseadas em uma associação injustificada entre otimização e única resposta correta), cria-se a expectativa da construção de uma proposta alternativa. (SILVA, 2016, p. 109)

Admitindo que estamos diante do incomensurável no sopesamento de princípios, ele apresenta uma solução tanto improcedente quanto inconsistente, com um certo jogo de palavras, mas peremptoriamente:

É justamente o contrário o que ocorre: ponderação só é exigível quando há incomensurabilidade, já que, se houver uma métrica comum entre duas coisas, não há ponderação, mas simples mensuração. Em nosso dia-a-dia, constantemente nos deparamos com opções incomensuráveis para as nossas ações e decisões. Isso, contudo, não impede nossas decisões e não as torna irracionais. (SILVA, 2016, p. 111)

Essa afirmação relaciona-se com o trabalho anterior em que Silva (2011, p. 282 ss) recorre à "teoria da paridade" de Ruth Chang (1997, esp. p. 7 e 18; 2002a) para justificar o seu argumento. Já antes, Silva defendera a distinção radical entre a otimização de Alexy e o modelo de Dworkin com o recurso a essa autora, afirmando "que pode haver frequentemente várias soluções para o mesmo problema em uma zona de paridade, dentro da qual qualquer resposta é de considerar-se ótima" (SILVA, 2007, p. 222) ${ }^{20}$, apontando para otimização do comparável (SILVA, 2007, p. 173 ss). Em primeiro lugar, essa tentativa de juntar uma teoria que parte de que o sopesamento de princípios é indissociável da otimização - "a otimização em relação a princípios colidentes nada mais é do que o sopesamento" (ALEXY, 2002, p. 401 [trad. bras. 2008, p. 594]) - com uma teoria comparativista em relação a valores, aplicável ocasionalmente até mesmo aos desejos brutos em escolhas triviais (Chang, 2002b, p. 64), para justificar a correção do modelo de Alexy, parece-me problemática. Embora considere a otimização, Ruth Chang (2002b, p. 46 ss) distingue, em primeiro lugar, sopesamento tanto de

${ }^{20}$ Cf. Silva (2002, p. 204-206). 
comparação quanto de otimização, nos termos de correspondência eletrônica a este autor:

Quanto a Alexy, sopesamento per se não implica comparabilidade porque você pode ter uma regra que determina o equilíbrio e, assim, a comparação não decorre de um genuíno sopesamento dos méritos das alternativas. Nem sopesamento implica otimização como você corretamente diz. (CHANG, 2015, tradução livre) $)^{21}$

Além disso, Chang (2002b, p. 60) sustenta que a comparação "vai além da otimização", particularmente porque, "diferentemente da otimização, ela [a comparação] nega que todas as razões justificantes são comparações das alternativas; uma razão justificante não precisa ser o fato de que a alternativa é ótima com respeito ao valor da escolha". Ou seja, não se trata de um modelo que restringe o sopesamento ou a comparação à otimização. Portanto, na zona de "paridade" de Chang a razão justificante não se orienta para uma solução ótima. Ao contrário, ela esclarece em outra correspondência a este autor a respeito de uma de suas passagens sobre otimização:

Eu estava pensando de otimização como tricotomia pressuposta - que as únicas possibilidades de comparação são 'melhor', 'pior' e 'igual'. Antes da paridade, otimização era a única forma de comparação. Mas, uma vez que permitimos paridade, temos uma nova forma de comparação, que abre espaço para a paridade. (CHANG, 2017, tradução livre) ${ }^{22}$

Portanto, a paridade no sentido de Chang implica uma forma de comparação que é alternativa à otimização ou visa superá-la. Parece-me que quem entrou na "fórmula do peso" de Alexy dela ficou refém, não tendo condições de dar um salto para fora na busca de suplementos em teorias mais nuançadas como o comparativismo de Chang. Pelo menos na forma da tentativa de Silva.

Com esse embaralhamento de Chang com Alexy, Silva torna difícil a compreensão de meu ponto de vista. Minha crítica à otimização dirigiu-se exatamente ao fato de que Alexy (ao que me parece corretamente) relaciona-a à comensurabilidade. Alexy é claro a esse respeito, sustentando que haveria não apenas "comparabilidade", mas também "comensurabilidade" dos direitos fundamentais a partir de um "ponto de vista unitário: o ponto de vista da Constituição" (ALEXY, 2003, p. 781). Sejamos mais explícitos agora:

${ }^{21}$ No original: "As for Alexy, balancing per se doesn't entail comparability b/c you could have a rule that determines the balance and so the comparison doesn't come from a genuine balancing of the merits of the alternatives. Nor does balancing entail optimization as you rightly say".

${ }^{22}$ No original: "I was thinking of optimization as presupposing 'trichotomy' - that the only possibilities for comparison are 'better', 'worse', and 'equal'. Before parity, optimizing was the only form of comparativism. But once we allow for parity, we have a new form of comparativism, one that makes room for parity". 
O conceito de comparabilidade da significação para a Constituição contém dois elementos que são suficientes para fundar a comensurabilidade. O primeiro é um ponto de vista unitário: o ponto de vista da Constituição. [...] $\mathrm{O}$ segundo elemento fundante da comensurabilidade é escala obtida seja como for, que ofereça os graus para a avaliação das perdas e ganhos dos direitos fundamentais. A escala triádica $l, m$, s é um exemplo disso. (ALEXY, 2003, p. 781-782)

A esse respeito, esclareci em meu livro:

Mas o problema da incomensurabilidade surge exatamente em virtude das diversas perspectivas em que a Constituição pode ser observada, numa sociedade diferenciada em uma multiplicidade de esferas sociais, cada uma delas com pretensão de autonomia. A esse respeito, é oportuno acrescentar que, segundo o próprio modelo de Alexy (2000, p. 38), a Constituição (os seus princípios) é objeto da ponderação (...). E o problema da incomensurabilidade surge precisamente por força desse paradoxo: a Constituição é, ao mesmo tempo, critério e objeto da ponderação. É verdade que, com uma "fórmula do peso", na qual as variáveis são formalizadas ("escala triádica"), é possível tornar estas comensuráveis (cf. Alexy, 2003, esp. p. 782; ver também 2008, p. 599 ss [2002, p. 405 ss]). No entanto, se retornarmos à dimensão do conteúdo, o problema da incomensurabilidade, então reprimido, reaparecerá de forma incontrolável. (NEVES, 2013, p. 149-150, nota 138)

Uma fórmula sintática, embora tenha um valor de ordenação lógica, não entra no campo arenoso do semântico e do pragmático, muito menos torna o incomensurável em comensurável. De qualquer maneira, meu argumento dirigiu-se à obra de Alexy, para quem os direitos fundamentais e os respectivos princípios seriam comensuráveis e, portanto, estariam sujeitos ao sopesamento otimizante.

No entanto, Silva tenta salvar o modelo de otimização de Alexy, estranhamente, alegando, agora, que apenas o incomensurável é sujeito ao sopesamento, pois o comensurável apenas se mensura. Esse é um momento infeliz na obra de Silva. Em primeiro lugar, porque o recurso a Chang e sua compatibilização com a "fórmula do peso" de Alexy é altamente discutível: por um lado, Chang admite, como esclarecido acima, tanto o sopesamento em geral quanto a comparação em especial não otimizante; por outro, Chang não admite apenas a comparação do incomensurável, que "não pode ser medido precisamente", mas também a comparação do comensurável na escala cardinal, "classificado precisamente em alguma unidade de valor" (CHANG, 1997, p. 02).

Além disso, o jogo de palavras de Silva não procede. O comensurável apenas se mensura, diz ele. Claro que uma grandeza mensurável isoladamente ainda não é sopesável. Entretanto, quando se comparam duas ou mais grandezas mensuráveis para definir uma escolha, torna-se possível o sopesamento (balancing, weighing). Consideremos um comerciante ou um colegiado de uma empresa diante da escolha de 
um preço ou de outros (valores monetariamente comensuráveis) para um dos seus produtos em face de um mercado complexo e prenhe de incertezas: ambos estão constrangidos a sopesar valores comensuráveis assumindo riscos, inclusive se houver a orientação para otimizar a curto prazo o lucro decorrente diretamente da venda do produto. O sopesamento importa basicamente um cotejamento, que inclui também o comensurável. O termo está etimologicamente relacionado ao cotejamento de grandezas comensuráveis, passando a ser empregado para comparar $\mathrm{o}$ incomensurável de maneira metafórica, como, às vezes, parece sugerir a própria Chang (2002b, p. 48, 152-153, nota 26), embora a sua orientação argumentativa seja diversa.

Considerando que se sopesa e se compara tanto grandezas comensuráveis quanto grandezas incomensuráveis, meu argumento é que, em relação a estas, a otimização como uma máxima amparada em uma fórmula lógico-sintática é uma pura ilusão. Eventualmente, no mundo do contingente, pode surgir um resultado "ótimo". E mesmo se fosse admitida a otimização do incomensurável na escala ordinal, isso decorreria de um sujeito da "escolha racional" (em um sentido amplo dessa expressão), como enfatiza Chang (2002b, p. 46). Essa suposição de um sujeito da escolha racional não me parece adequada, porém, para tomadas de decisão envolvendo um aparato institucional complexo, em que vários atores estão envolvidos transsubjetivamente na rede discursiva: juiz ou tribunal, partes, advogados, ministério público, terceiros interessados, público etc. E mesmo na perspectiva da escolha racional caberia questionar se, ao "classificar ordinalmente" ou "classificar em uma lista" (CHANG, 1997, p. 02) para otimizar, não se supõe que haja uma prévia, mesmo implícita, atribuição de valor mesurável às alternativas a serem postas na lista para que haja condições da própria otimização nos termos de uma comensurabilidade frágil ou indireta, ao contrário de uma lista altamente volátil, flexível e imprecisa do incomensurável, imprópria para otimização. Considere-se que, inclusive no campo da escolha racional referente a grandezas comensuráveis, os modelos de otimização foram questionados, inclusive quando suposto que se possa alcançar o ótimo: o desgaste para definir e alcançar o ótimo seria contraproducente, cabendo assumir o risco de suspender a comparação quando houvesse "algo suficiente", "satisfatório" 23 .

A própria Chang, embora entenda que "'ser suficientemente bom' é, na superfície das coisas, um fato não comparativo" e que "satisfazer [satisficing] não é uma teoria plausível sobre a racionalidade - apesar de poder soar como uma teoria da deliberação ou do pensamento racional" (CHANG, 2016, p. 228, 230), admite que, "embora, em pelo menos uma interpretação, apresente uma alternativa para otimização, satisfazer não mina a tese comparativista", desde que "coloca um genuíno desafio para o comparativismo" (CHANG, 2002b, p. 51). Similarmente, não entendo que o modelo de "satisfazer" seja incompatível com comparação, ao menos no sentido que se desenvolve a partir de Simon (1956a). Especialmente no campo institucional, transsubjetivo, envolvendo varáveis sistêmicas complexas e expectativas desestruturadas da esfera pública, o modelo de sopesamento comparativo impõe-se em caso de colisões de normas, mas a comparação interrompe-se de maneira racional

${ }^{23}$ Nesse sentido, ver Simon (1955, p. 110 ss; 1956a; 1956b). 
quando se apresenta uma solução satisfatória no balanceamento das expectativas normativas envolvidas, mesmo que um dos participantes alegue que se possa alcançar o "ótimo". Evidentemente, nessa perspectiva do "satisfatório", evita-se o sopesamento se, já no início da eventual colisão de uma das normas, apresenta-se uma solução satisfatória a partir de uma delas. Isso afasta a "compulsão ponderadora". Daí por que, nas circunstâncias transsubjetivas da concretização constitucional, contar com "todas as coisas consideradas" nos termos de Chang (2004), é inapropriado. E o modelo de "todas as coisas consideradas" seria compatível com o incomensurável?

Dessa maneira, ao assumir um modelo de "sopesamento comparativo", parti da noção de uma razão ou racionalidade precária. Como um modelo dirigido apenas ao contingentemente satisfatório, ele poderia ser reconduzido a uma ou mais fórmulas matemáticas, como o fez Simon (1956a, esp. p. 133-134). Mas isso não me parece necessário e mesmo oportuno no campo do incomensurável e em uma concepção sistêmica que considera o direito e os direitos em termos de transubjetividade, fora, portanto, do padrão da escolha racional. Como Alexy parte de um modelo da escolha racional e insiste que está a sopesar o comensurável, sua teoria da otimização é, nesse particular, consistente. O mesmo não se pode afirmar da proposta de Silva com sua ideia de que se sopesa apenas o incomensurável.

É interessante que Silva, em vários pontos de seu trabalho, exige, retoricamente, que eu explique certas afirmações e que aponte os casos em que foi aplicado o modelo comparativo, por fim, alegando que a "demonstração (...) não é encontrada no livro" (SILVA, 2016, p. 111, grifei). Embora meu trabalho tenha sido primariamente de teoria do direito, eu apontei casos e hipóteses em que se caracterizou ou se exigiria um tipo de sopesamento comparativo, considerando a alteridade básica do social e do jurídico, assim como a diversidade de sistemas sociais envolvidos. Entretanto, o mesmo que se me exige ou imputa eu poderia atribuir a Alexy e Silva: nenhum dos casos apresentados demonstram que houve uma orientação otimizante ou que houve otimização. Apenas apresentar uma fórmula sintática em relação aos casos nada diz sobre a otimização, pois estamos diante do incomensurável e fora da escolha racional de um sujeito idealizado que dispõe de uma "fórmula do peso". Ou Silva estaria exigindo que eu demonstrasse minha tese com uma fórmula matemática do sopesamento comparativo? Aqui não estamos no campo sólido da demonstração, mas sim no ambiente fluido da reconstrução teórica da prática jurídico-constitucional.

\section{SOBRE A APLICAÇÃO DOUTRINÁRIA E JURISPRUDENCIAL INCONSISTENTE DAS TEORIAS REFERENTES AOS PRINCÍPIOS E AO SOPESAMENTO NO BRASIL E SUAS IMPLICAÇÕES SOCIOLÓGICAS}

\section{Críticas concentradas - não esparsas - ao envolvimento de Virgílio Afonso da Silva no debate brasileiro}

No tópico 1 do seu artigo, sob o título "Algumas respostas a críticas esparsas", Virgílio Afonso da Silva reage às minhas críticas ao seu envolvimento no debate brasileiro das décadas 1990 e 2000 sobre princípios, proporcionalidade, sopesamento

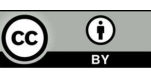

5 JOURNAL OF INSTITUTIONAL STUDIES 1 (2019)

Revista Estudos Institucionais, v. 5, n. 1, p. 269-316, jan./abr. 2019 
e temas afins. Em primeiro lugar, cabe insistir que não se trata de críticas esparsas, mas sim de críticas concentradas no capítulo IV do meu livro, especialmente nas páginas 182 a 189 em relação a Silva. Ao contrário do que afirma Silva, há uma separação metodológica clara entre a discussão crítica das teorias (capítulos I e II) e a proposta de uma nova teoria (capítulo III), por um lado, e a crítica à aplicação controversa dessas teorias no Brasil (capítulo IV), por outro. Minhas críticas à teoria de Alexy concentraram-se no tópico 3 do capítulo II e também foi desenvolvida em várias partes do capítulo III. As críticas a Silva concentraram-se no capítulo IV, como se observa de todas as passagens a que ele se refere no tópico 1 do seu trabalho.

Silva reage à minha crítica de que a sua censura aos autores brasileiros que incluíram o princípio da interpretação da lei conforme a constituição entre os princípios da interpretação constitucional também se aplicaria a Hesse. Apontei que Silva, na sua censura, sustentou que tal princípio "seria um critério específico de interpretação da lei" na obra de Hesse (NEVES, 2013, p. 183). Na sua resposta, reverbera, citando artigos de sua autoria em que afirma que, na interpretação conforme, tratar-se-ia também de um princípio de interpretação da lei, que seria o "seu objetivo principal". Acrescenta que "não pode ser considerada um princípio da interpretação constitucional" (SILVA, 2016, p. 99). Essa insistência não acrescenta nada à minha crítica a uma certa mentalidade colonial. É inegável que Hesse apresentava o princípio da interpretação conforme a constituição como algo que surgira "no mais novo desenvolvimento do direito constitucional" e que confirmava "a referência recíproca entre constituição e lei", incluindo "também a questão do conteúdo da Constituição pela qual a lei deve ser avaliada" (HESSE, 1969, p. 31, 34). Afirmar que ele também é um princípio da interpretação da lei (o que é óbvio) não tem nada a ver com a minha crítica. Minha crítica permanece sem reposta: a censura de Silva aos autores brasileiros caberia também a Hesse, não tendo havido erro dos autores brasileiros ao aplicarem Hesse nesse particular.

Virgílio Afonso da Silva também reage à minha crítica pontual à sua censura ao sincretismo metodológico. No geral, concordo com suas restrições ao sincretismo metodológico da doutrina constitucional brasileira dos anos 1990 e 2000. O meu argumento se refere a uma incapacidade de compreender teorias divergentes e admitir uma certa compreensão recíproca entre elas em pontos muito específicos. No caso, refiro-me às teorias de Friedrich Müller e Robert Alexy no ponto da ponderação. Silva deforma o meu pensamento, alegando que "ele conclui não há nada de incompatível entre as duas teorias" (SILVA, 2016, p. 100). Tal conclusão seria absurda. Eu estaria totalmente equivocado se a tivesse afirmado.

O que afirmei no livro diz respeito a um ponto específico. Vejamos com a incômoda citação do trecho:

Silva afirma que Müller sustenta um conceito de norma jurídica insuscetível de colisão e, pois, de ponderação, para, assim, apontar a contradição de sua teoria com a de Alexy. Está correto quanto ao fato de que a norma jurídica em Müller não se submete à ponderação. Mas a norma jurídica em Müller só surge no final do processo de 
concretização. Dessa maneira, ela corresponde, no modelo de Alexy, à regra jurídica construída, após a ponderação, como razão definitiva de uma decisão judicial. E, conforme este, nenhuma regra (completa), como razão definitiva, é suscetível de ponderação. Nesse sentido, não haveria nada de problemático entre as duas teorias. Dados os pressupostos teóricos diversos, a diferença estaria no significado da ponderação antes do final da cadeia de concretização ou de argumentação, respectivamente: para Müller, durante a concretização, a ponderação apresenta-se como um fator potencialmente irracional no processo de produção da norma jurídica que fundamenta a norma de decisão do caso; em Alexy, a ponderação, tanto no caso de princípios quanto de regras incompletas, seria o elemento decisivo na argumentação destinada a construir a regra (completa) como razão definitiva para a norma concreta de solução do caso. Problemas permanecem de ambos os lados, persistindo as seguintes indagações: antes do final do processo de concretização não haveria norma jurídica vinculando os juízes (para Müller)? É possível falar em regras completas como razões definitivas antes que se encerre o processo argumentativo em controvérsias constitucionais complexas (para Alexy)? Mas a resposta a essas questões não se encontra na busca de conciliação de ambas as teorias, tampouco na adoção incondicional de uma delas, mas antes em reflexões que busquem alternativas teóricas a esses modelos. (NEVES, 2013, p. 186-187, grifei $)^{24}$

Nada nesse trecho diz respeito a uma compatibilização das teorias. Aponto para limites da avaliação equivocada de um ponto específico da relação entre ambas teorias por Silva. Não me limitei a considerar as oito páginas em que Alexy resume de forma simplificada a obra de Müller (ALEXY, 1986, p. 63-70 [trad. bras. 2008, p. 76-84]). Considerei as duas teorias concorrentes em sua integridade, não como grandezas estanques e definitivas, para esclarecer pontos específicos. Minha preocupação é que nos limitemos inocentemente a lutar por teorias de alhures como modelos integralmente excludentes, sem uma reflexão apropriada sobre os nossos problemas constitucionais.

Por fim, Virgílio Afonso da Silva reage à minha crítica de que, "em parte (no que concerne ao local e ao universal), as objeções feitas por Silva aos autores brasileiros, nesse contexto, são aplicáveis a ele" (NEVES, 2013, p. 187) ${ }^{25}$. Silva pretende descaracterizar minha crítica como se eu não admitisse influências jurídicocomparativas entre ordens jurídicas e respectivas teorias ou doutrinas, o que "impediria uma recepção internacional" (SILVA, 2016, p. 100-101), assim como, em relação ao meu argumento de que a teoria de Alexy também tem perdido fôlego na jurisprudência do Tribunal Constitucional Federal da Alemanha, argui que a teoria é totalmente independente da prática (SILVA, 2016, p. 101).

Evidentemente é correto dizer que "minha preferência por essa ou aquela teoria não tem relação com os tribunais que a adotam" (SILVA, 2016, p. 101). Não poderia

${ }_{24}$ Nesse trecho cito Silva (2005, p. 135-137); Müller (1995, p. 62-63, 67; 1994, p. 208 ss; 1990, p. 21 ss).

${ }^{25}$ Cf. Silva (2005, p. 118-121). 
ser diferente. Mas também é inegável que a teoria ou a doutrina jurídica só têm sentido se constituem uma reflexão adequada de práticas jurídicas historicamente limitadas e, dessa maneira, são aptas a contribuir para a racionalização dessas práticas. Alexy baseou-se estritamente na jurisprudência constitucional alemã - "fixação em Karlsruhe" (HÄBERLE, 1987, p. 139) - em sua reconstrução teórica dos direitos fundamentais no âmbito da teoria dos princípios, especialmente no que concerne à máxima da proporcionalidade nos seus três níveis, tão conhecida nos exercícios para exames das faculdades de direito na Alemanha. Ao falar que mesmo na Alemanha essa teoria é expressamente questionada na prática jurisprudencial, apenas lateralmente quis advertir para a discutível pretensão de sua universalidade.

A universalidade da teoria de Alexy para o direito constitucional tem sido defendida por alguns dos seus discípulos mais açodados, particularmente no que concerne à proporcionalidade (KLATT; MEISTER, 2012). ${ }^{26}$. Minha crítica a Silva não se referiu primacialmente à simples pretensão de universalidade, embora também a questione, mas antes à recepção acrítica de uma teoria ou doutrina jurídica como se ela guardasse um quê de universalidade e fosse aplicada diretamente no contexto de toda e qualquer ordem jurídica. Em nenhum momento neguei o intercâmbio comparativo de teorias jurídicas, tendo eu mesmo proposto uma teoria de entrelaçamento entre ordens jurídicas que vai muito além do mero comparativismo jurídico, a saber, o transconstitucionalismo (NEVES, 2009). O que me preocupava e ainda me preocupa é a crença de que há teorias definitivamente superiores porque surgiram em ambientes acadêmicos dominantes. Embora considerando a importância da precisão na recepção de teorias, apontei até mesmo para o perigo de tornar o debate constitucional em uma questão terminológica, nos termos em que Silva vinha desenvolvendo (NEVES, 2013, p. 188). Daí por que enfatizei:

\begin{abstract}
Nesse sentido, o constitucionalista, no âmbito da ordem receptora, pode passar a ser antes um censor do uso correto da terminologia construída a partir de um modelo teórico fundado na reconstrução dogmática da prática constitucional de uma ordem jurídica estrangeira. Em suma: em vez de "controlar" a teoria, doutrina e prática constitucional brasileira a partir desse modelo, cabe refletir sobre as deficiências teóricas e práticas que obstaculizam, no Brasil, o desenvolvimento de um direito constitucional que se oriente no sentido da tomada de decisões juridicamente consistentes e socialmente adequadas; com base nessa reflexão, podem ser alcançadas as condições para o surgimento de teoria(s) constitucional(is) que, partindo da reconstrução dogmática da prática constitucional, contribua(m) decisivamente para o aperfeiçoamento da jurisdição constitucional. (NEVES, 2013, p. 189)
\end{abstract}

${ }^{26}$ Para uma crítica, ver Reimer (2013). 
Minha preocupação era apenas com a recepção acrítica, a absolutização de uma teoria nascida alhures, com a consequente incapacidade reflexiva em relação ao material da experiência jurídica brasileira, especialmente com quebra da historicidade e desconhecimento quase absoluto dos autores brasileiros do passado. Um sintoma disso é a própria conclusão de Silva a respeito do debate sobre métodos de intepretação constitucional no Brasil. Ele se restringe a praticamente repetir (sem citar diretamente) uma afirmação de Böckenförde em 1976: "necessidade de uma teoria (vinculante) da Constituição" (Böckenförde, 1991, p. 81). ${ }^{27}$ Mas que teoria? A de Alexy à moda brasileira? Parece-me muito pouco!

\title{
2. Crítica ao abuso de princípio e à inconsistência jurídica da doutrina e prática jurídicas brasileiras
}

Virgílio Afonso da Silva, no tópico 8 do seu artigo, também censura minhas críticas ao abuso de princípios na experiência brasileira. Antes, porém, mais uma vez, ele deforma meu argumento, vinculando-me ao seguinte argumento atribuído a outros autores: "o argumento costuma ter a seguinte estrutura: juízes por todo o Brasil, em todos os níveis, têm tomado as decisões mais disparatadas com base em sopesamentos de princípios, logo a teoria dos princípios deve ser rejeitada" (SILVA, 2016, p. 107).

Não há nada minimamente próximo desse raciocínio em minha obra, até porque eu mesmo ofereco também uma teoria dos princípios (talvez a confusão se explique porque, ao que tudo indica, para Silva, a única teoria dos princípios possível é a de Alexy). O que afirmo no meu trabalho é que o abuso de princípios na forma atual está relacionado com a deficiente autonomia operativa do sistema jurídico, a baixa concretização normativo-jurídica consistente da Constituição, nos seguintes termos:

\begin{abstract}
A história constitucional brasileira é marcada por esse problema de baixa capacidade de reprodução constitucionalmente consistente do direito. Tanto no passado quanto no presente, a partir de pressupostos teóricos diversos, vem-se apontando para esse problema. Não é aqui o lugar para uma análise desse pano de fundo sociológico. Mas essa questão tem efeitos na prática e na dogmática jurídico-constitucional. (NEVES, 2013, p. 190)
\end{abstract}

Silva cita trecho em que afirmo que "os princípios são mais apropriados a abusos no processo de concretização", mas não considera o contexto: "pois eles estão vinculados primariamente ao momento de abertura cognitiva do direito" e porque, pertencendo à "estrutura de reflexividade, que nunca, em si mesmo, alcança definitividade, podem mais facilmente ser articulados para encobrir soluções que minam a consistência da ordem jurídica a favor de interesses particularistas que pressionam a solução do caso" (NEVES, 2013, p. 190-191).

Silva (2016, p. 107-108), porém, sustenta que eu crio uma relação quase necessária entre o recurso a princípios e a falta de autonomia do direito. Isso não procede. Eu

${ }^{27}$ Cf. Silva (2005, p. 143) e Neves (2013, p. 184, nota 39). 
deixo claro em relação aos princípios: "Quando funcionam em um Estado constitucional rigorosamente consistente (autorreferência), eles desempenham um papel fundamental para adequar o direito à sociedade (heterorreferência)" (NEVES, 2013, p. 191).

O que afirmo é uma relação de abuso de princípios e falta de autonomia do direito em dado contexto histórico. E evidentemente meu argumento não tem nada a ver com a insinuação de que "a jurisprudência brasileira anterior à 'descoberta' da teoria dos princípios era um exemplo de consistência, coerência, objetividade e racionalidade, características que teriam sido então destruídas pelos fascínios pelos princípios", nem com a seguinte inferência:

A crítica de Neves, que vê nos princípios o canal pelo qual os interesses particularistas entram no direito e minam a sua autonomia, parece supor que, antes dos princípios, essa autonomia estava presente e as regras, às quais se dava o devido valor, impediam que interesses econômicos, políticos, relacionais, familiais impusessem bloqueios contra a realização daquilo que a constituição prevê. (SILVA, 2016, p. 108)

Meu argumento não é tão simples. Meus trabalhos há anos apontam para problemas de inconsistência da reprodução jurídica no Brasil ${ }^{28}$. O pseudoformalismo das regras, em certa fase, nunca escondeu essa inconsistência, no âmbito de uma "legalidade seletiva". O que é diferente no recurso abusivo aos princípios e ao sopesamento em contextos como o brasileiro diz respeito ao fato de que, como já dito, os princípios, quando abusados, são mais apropriados para "encobrir soluções que minam a consistência da ordem jurídica a favor de interesses particularistas que pressionam a solução do caso". Acrescente-se que, em minha teoria, a consistência jurídica só está garantida se ela está articulada com a adequação social do direito, no processamento do paradoxo da tensão e complementaridade entre princípios e regras mediante, respectivamente, argumentos substanciais e formais (NEVES, 2013, p. 223 ss).

Mas Silva (2016, p. 108) exige-me “demonstração empírica" do problema da inconsistência jurídica e da falta de autonomia do direito no Brasil. Não é possível retomar toda a demonstração empírica a cada novo momento que há referência a uma tese. Já em trabalho de 1992 (NEVES, 1992), ao qual Silva se refere (SILVA, 2016, p. 115, nota 51), mas não leva devidamente em consideração, apresento um conjunto de comprovações empíricas da falta de autonomia do direito na experiência histórica brasileira, dele tendo resultado trabalhos mais concretamente empíricos sobre essa questão ${ }^{29}$. Fiz referência a esse trabalho e a obras de outros autores que, apesar de outros pressupostos teóricos, chegam a resultado semelhantes (NEVES, 2013, p. 190). Em um comentário lateral, é óbvio que não poderia novamente apresentar todo

${ }_{28}$ A partir de Neves (1992).

${ }^{29}$ Destaca-se Costa (2012).

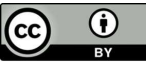


material empírico processado no passado. Para isso servem as remissões. Sim, chamo atenção no livro sobre princípios e regras para o fato de que o abuso de princípios é mais um (e o novo) episódio em que se reproduz a inconsistência jurídicoconstitucional no Brasil, enfatizando que os princípios e o sopesamento têm, nas novas circunstâncias, servido mais apropriadamente para encobrir, pelo fascínio, a inconsistência jurídica. E não deixei de apontar, em caráter secundário, para casos jurisprudenciais como demonstração empírica no item 2 do capítulo IV do livro, inclusive um caso do passado. Entretanto, quando se faz uma obra minimamente complexa e diversificada, não monotônica, não se pode trazer todos os argumentos e todas as demonstrações a todo momento.

\section{POR QUE O JUIZ IOLAU?}

No tópico 10 do seu artigo, em conclusão, Virgílio Afonso da Silva critica a introdução, em minha teoria, da figura metafórica do Juiz Iolau, que seria uma tentativa frustrada de me diferenciar da "teoria [no singular] dos princípios". Nas suas palavras, "essa tentativa derradeira também é frustrada" (SILVA, 2016, p. 112). Ele, então, alega, sempre insistindo, com certeza inabalável, na superioridade da teoria de Alexy:

Tenho certeza de que, se Iolau ler Alexy e outros defensores da teoria dos princípios com um pouco mais de calma, irá perceber que a otimização não apenas não rejeita, mas, ao contrário, exige a consideração de todos os fatores que Marcelo Neves afirma que ela despreza. (SILVA, 2016, p. 112)

Por fim, critica a minha formulação, em outro contexto do livro, no qual afirmo, na análise de um acórdão específico do Supremo Tribunal Federal, que "não é relevante [aqui] discutir a incompatibilidade desse argumento contido no voto que serve de esteio à maioria com as concepções dos autores invocados" (SILVA, 2016, p. 112), retirando o advérbio "aqui" do original em sua citação ${ }^{30}$. A partir daí, conclui peremptoriamente que, "segundo ele [eu], é irrelevante saber se aquilo que um juiz diz é de fato compatível com a teoria que ele afirma usar" (SILVA, 2016, p. 113).

Comecemos com essa última objeção. Concordaria plenamente com Silva em afirmar que seria um absurdo se um autor qualquer dissesse que é irrelevante saber se aquilo que um juiz diz é compatível com a teoria que ele afirma usar, mesmo porque não separo teoria e prática de forma estanque como ele. Mas isso não tem nada a ver com o que disse nas páginas 211 e 212 do meu trabalho. Naquele momento estava a discutir a inconsistência da aplicação de modelos de princípios na jurisprudência do Supremo Tribunal Federal. Eu pus um parêntese - e aqui não é inoportuna uma vaga referência à atitude filosófica de Edmund Husserl ${ }^{31}$ e à atitude metódica de Guerreiro Ramos (1996, p. 72) -, suspendendo, naquele momento específico, a discussão da

${ }^{30}$ Cf. Neves (2013, p. 211).

${ }^{31}$ Husserl (1982, p. 86-88), em outro contexto teórico. Cf. também Habermas (1978, p. 25).

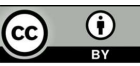


compatibilidade do acórdão do STF, no voto do ministro relator Carlos Brito, com as teorias citadas. Tendo em vista que já havia discutido as teorias de Alexy e Dworkin no particular, entendia que já estava implícito, naquele momento argumentativo, que a referência do ministro a Alexy (e, com ele, a Silva) e Dworkin, no sentido de afirmar uma sorte de primazia absoluta da liberdade de expressão por sopesamento antecipado da Constituição, era incompatível com as teorias desses autores. Mas não deixei de apontar para o absurdo da aplicação nos termos da minha teoria. Afirmei, então, serem "absurdas" as "consequências" da tese afirmada pelo Ministro Carlos Britto de que a "precedência da liberdade de expressão é daquela que se põe em toda e qualquer situação concreta", desenvolvendo argumentos teóricos sobre a inconsistência daquela aplicação, inclusive em comparação com outros casos (NEVES, 2013, p. 212 ss). Se afastássemos os parênteses reflexivos naquele e em outros momentos argumentativos, cairíamos no borbotão mental inconsequente e seríamos incapazes de desenvolver argumentos específicos na cadeia da argumentação.

Quanto à certeza de Silva de que, se Iolau lesse Alexy, adotaria a sua teoria, pareceme que estamos diante de um dogmatismo de um "único autor correto". Silva não apresenta nenhum argumento convincente a esse respeito. O Juiz Iolau não é um Juiz Hercúleo à maneira de Dworkin (eu diria um juiz maximizante) nem um juiz otimizante à maneira de Alexy. Ele é um juiz que admite um sopesamento comparativo de caráter não otimizante. Sobre essa possibilidade, há elementos claros mesmo na teoria da própria Ruth Chang, tão cara a Silva (ver supra p. 296 ss). Eu ainda vou além para afirmar que quando sopesa, Iolau orienta-se pelo "satisfatório", por que trabalha com exclusões de variáveis e, sobretudo, admite paralisação da comparação quando entende "ser suficiente". Portanto, apesar de procurar considerar as diversas perspectivas envolvidas no caso, ele não é um juiz que "considera todas as coisas", pois sabe que isso é impossível. Ele sabe da necessidade do caráter seletivo e da precariedade de sua racionalidade. Em vez da crença na maximização ou na otimização, mesmo como ideais, ele considera o caráter hard dos conflitos subjacentes aos casos controversos, não banalizando fórmulas matemáticas de caráter simplório. O Juiz Iolau, ele mesmo um paradoxo entre abertura cognitiva e fechamento normativo, princípios e regras (e híbridos!), equilibra-se com dificuldade entre argumentos formais e substanciais, sem pretensão de ter a última palavra. Ele é dialógico e capaz de aprendizados com outras esferas do Estado e com a própria sociedade civil e esfera pública, sem desconhecer o seu papel seletivo. Ele está mais próximo da "humildade judicial" nos termos de Cass Sunstein (2009, p. 143, 165 ss). Se ele lesse/ler Alexy, ficaria/ficará desapontado com a sua pretensão otimizante.

\section{CONCLUSÃO: RISCO DE TORNAR-SE “ENVIADO” DE UM PROFETA}

A resenha crítica de Virgílio Afonso da Silva, um conhecedor profundo da teoria dos princípios de Robert Alexy, sobre o meu livro "Entre Hidra e Hércules" é louvável e bem-vinda. Ela serve não apenas para que eu possa apresentar certos esclarecimentos sobre minha obra e "pôr os pontos nos is", mas também para que possa desenvolver novas reflexões sobre pontos que não foram suficientemente considerados em meu trabalho. Entretanto, nessa oportunidade, gostaria de alertar para o "risco de se tornar 
enviado de um profeta".

Esclareçamos. No comentário à carta de Paulo aos romanos, Giorgio Agamben aponta para o papel de apóstolo (uma figura eminentemente religiosa), assumido por Paulo, distinguindo-o do seu precedente hebraico, o "enviado" [šaliah], "um mandatário, um homem enviado para uma incumbência determinada": "Essa figura originalmente jurídica adquiriu no judaísmo um significado religioso [...]. Mas se tratava sempre, mesmo quando a incumbência tinha um caráter religioso, de uma tarefa determinada e de uma figura sem demasiadas pretensões" (AGAMBEN, 2000, p. 60 [trad. bras. 2016, p. 77]). O "enviado" [šaliah] não tinha a capacidade interpretativa e reflexiva que se expressava na figura do apóstolo, restringindo-se a transmitir mensagens ou cumprir tarefas.

É muito salutar que jovens brasileiros façam estudos de pós-graduação, especialmente doutorado, em centros acadêmicos dominantes no exterior, sobretudo em centros de excelência e com professores renomados. Isso serve para revigorar os nossos debates e ampliar nosso horizonte de pesquisas. Entretanto, tem-se tornado muito comum que jovens acadêmicos das ciências sociais, da filosofia e particularmente do direito, sem certos pressupostos teóricos, sigam para o exterior e estudem com uma dessas figuras academicamente proeminentes por quatro anos, para retornar como um mero repetidor ou, no máximo, preciso aplicador de uma das teorias em que foi adestrado. Por um lado, a capacidade crítica e reflexiva em relação ao respectivo autor ou modelo teórico, que é elevado ao suprassumo indiscutível da verdade, tende a ficar reduzida ou a ser eliminada. Por outro lado, a experiência histórica do pensamento no nosso país é quase totalmente desconsiderada, sendo rompida a cada leva de acadêmicos que trazem uma nova teoria. Isso talvez seja produto de um certo colonialismo cultural, já existente no passado. Mas, ao contrário do bacharelismo no passado, marcado pelo ecletismo, onde os "enviados" eram confusamente "politeístas" e decantavam as mensagens dos profetas como papagaios desafinadamente polifônicos, há uma nova tendência: muitos retornam após o adestramento por um professor proeminente de alhures, tornando-se não propriamente discípulos, mas "enviados" coerentemente monoteístas de um "profeta". Esse risco está presente cada vez mais. Quand o se consuma, ele é não apenas altamente prejudicial à construção de um modelo de reflexão teórica e doutrinária ou dogmática que seja apropriado ao nosso contexto jurídico-constitucional e adequado ao aperfeiçoamento das respectivas práticas institucionais, mas também obstaculiza uma possível influência de um tal modelo no âmbito jurídico-comparativo. Contra esse "risco do enviado", cabe hoje mais do que nunca uma atuação incisiva no meio acadêmico brasileiro, especialmente nas faculdades de direito. Estes comentários também servem a esse propósito. 


\section{REFERÊNCIAS}

AGAMBEN, Giorgio. Il tempo che resta: un commento alla Lettera ai Romani. Turim: Bollati Boringhieri [trad. bras.: $\mathrm{O}$ tempo que resta: Um comentário à Carta aos Romanos. Belo Horizonte: Autêntica, 2016], 2000.

ALEXY, Robert. Theorie der Grundrechte. Frankfurt am Main: Suhrkamp [trad. bras.: Teoria dos direitos fundamentais. São Paulo: Malheiros, 2008], 1986.

ALEXY, Robert. Die Institutionalisierung der Menschenrechte im demokratischen Verfassungsstaat. In: GOSEPATH, Stefan; LOHMANN, George (orgs.). Philosophie der Menschenrechte. Frankfurt am Main: Suhrkamp, p. 244-264, 1998.

ALEXY, Robert. Zur Struktur der Rechtsprinzipien. In: SCHILCHER, Bernd; KOLLER, Peter; FUNK, Bernd-Christian (orgs.). Regeln, Prinzipien und Elemente im System des Rechts. Viena: Verlag Österreich, p. 31-52, 2000.

ALEXY, Robert. Postscript. In: ALEXY, Robert. A Theory of Constitutional Rights. Trad. ingl. Julian Rivers. Oxford: Oxford University Press, p. 388-425 [trad. bras. Virgílio Afonso da Silva. Teoria dos direitos fundamentais. São Paulo: Malheiros, p. 575-627, 2008], 2002.

ALEXY, Robert. Die Gewichtsformel. In: JICKELI, Joachim; KREUTZ, Peter; REUTER, Dieter (orgs.). Gedächtnisschrift für Jürgen Sonnenschein. Berlim: De Grutyer, p. 771-92, 2003.

ALMEIDA, Fábio Portela L. The Emergence of Constitutionalism as an Evolutionary Adaptation. Cardozo Public Law, Policy \& Ethics Journal, vol. 13, n. 1, p. 01-96, 2014.

BERNSTORFF, Jochen von. Kerngehalte im Grund- und Menschenrechtsschutz: Eine vergleichende Studie zur Einschränkbarkeit nationaler und völkerrechtlicher Freiheitsgarantien. Heidelberg: Tese de livre docência apresentada à Universidade de Frankfurt am Main. 2010. 
BERNSTORFF, Jochen von. Proportionality Without Balancing: Why Judicial Ad Hoc Balancing is Unnecessary and Potentially Detrimental to the Realization of Individual and Collective Self-Determination. In: LAZARUS, L. et al. (orgs.).

Reasoning Rights: Comparative Judicial Engagement. London/Portland: Hart, p. 6386, 2014.

BOBBIO, Norberto. Il futuro della democrazia. In: BOBBIO, N. Il futuro della democrazia: il comune denominatore di tutte le questioni politicamente rilevanti. Turim: Giulio Einaudi [trad. bras. “O futuro da democracia; uma defesa das regras do jogo". Rio de Janeiro: Paz e Terra, p. 17-40, 1986], 1995.

BÖCKENFÖRDE, Wolfgang. Methoden der Verfassungsinterpretation Bestandaufnahme und Kritik. In: BÖCKENFÖRDE, W. Staat, Verfassung, Demokratie: Studien zur Verfassungstheorie und zum Verfassungsrecht. Frankfurt am Main: Suhrkamp, p. 53-89, 1991 [originalmente em: NJW, 1976].

BOEHM, Christopher. Hierarchy in the Forest: The Evolution of Egalitarian Behavior. Cambridge, MA: Harvard University Press, 1999.

CARRIÓ, Genaro R. Notas sobre derecho y lenguaje. 3. ed. Buenos Aires: AbeledoPerrot, 1986.

CHANG, Ruth. Introduction. In: Chang, R. (org.). Incommensurability, Incomparability, and Practical Reason. Cambridge-MA/London: Harvard University Press, p. 01-34, 1997.

CHANG, Ruth. Against constitutive incommensurability or buying and selling friends. Nôus 35, Supplement: Philosophical Issues, v. 11, p. 33-60, 2001.

CHANG, Ruth. Possibility of Parity. Ethics, v. 112, n. 4, p. 659-688, 2002 (2002a).

CHANG, Ruth. Making Comparisons Count. London: Routledge, 2002 (2002b).

CHANG, Ruth. All Things Considered. Philosophical Perspectives, v. 18, p. 01-22, 2004. 
CHANG, Ruth. Correspondência eletrônica ao autor. 30 de julho de 2015.

CHANG, Ruth. Comparativism: The Grounds of Rational Choice. In: LORD, E.; MCGUIRE, B. (orgs.). Weighing Reasons. Oxford: Oxford University Press, p. 213240, 2016.

CHANG, Ruth. Correspondência eletrônica para o autor. 16 de junho de 2017.

COSTA, Antônio Carlos Luz da. Irritationen und Allopoiesis im Rechtssystem: eine systemtheoretische Analyse der polizeilichen Beobachtung in der Stadt Teixeira de Freitas, Brasilien. Tese de doutorado aprovada pelo Departamento de Sociologia da Universidade de Hamburgo em 2012.

DAVIDSON, Donald. On the very idea of a Conceptual Scheme (1974). In:

DAVIDSON, D. Inquiries into Truth and Interpretation. Oxford: Clarendon Press, p. 183-198, 1984.

DEWEY, John. The Public and its Problems: An Essay in Political Inquiry. Chicago: Gateway Books, 1946 [1ํㅜ ed. 1927].

DEWEY, John. Democracy and Education. An Introduction to the Philosophy of Education. New York: Macmillan Company, 1963 [1ª ed. 1916].

DWORKIN, Ronald. Hard Cases. Harvard Law Review, v. 88, n. 6, p. 1057-1109, 1975.

DWORKIN, Ronald. Taking Rights Seriously. 2aimpressão com apêndice (Londres: Duckworth) [trad. bras.: Levando os direitos a sério. São Paulo: Martins Fontes, 2002], 1978.

DWORKIN, Ronald. Law's Empire. Cambridge, MA/Londres: Harvard University Press [trad. bras.: O império do direito. $2^{\underline{a}}$ impressão. São Paulo: Martins Fontes, 2003], 1986. 
ESSER, Josef. Grundsatz und Norm in der richterlichen Fortbildung des

Privatrechts. Tübingen: Mohr, 1956.

FISCHER-LESCANO, Andreas. Systemtheorie als kritische Gesellschaftstheorie. In: FISCHER-LESCANO, A. (org.). Kritische Systemtheorie: Zur Evolution einer normativen Theorie. Bielefeld: Transcript Verlag, p. 13-39, 2013.

HABERMAS, Jürgen. Theorie und Praxis. Sozialphilosophische Studien. Frankfurt am Main: Suhrkamp, 1978.

HABERMAS, Jürgen. Zur Rekonstruktion des Historischen Materialismus. 3. ed. Frankfurt am Main: Suhrkamp, 1982.

HÄBERLE, Peter. Alexy, Robert, Theorie der Grundrechte. Baden-Baden 1985, Nomos. 548 S. (resenha). Der Staat, v. 26, p. 135-141, 1987.

HEGEL, G. W. Vorlesungen über die Philosophie der Geschichte, v. I: Die Vernunft in der Geschichte. Leipzig: Meiner, 1917 [1ª ed. 1837].

HESSE, Konrad. Grundzüge des Verfassungsrechts der Bundesrepublik

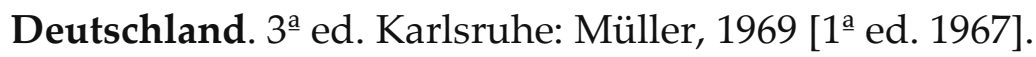

HOBBES, Thomas. Leviathan. TUCK, Richard (Org.). Cambridge: Cambridge University Press [1ª ed. London, 1651] [trad. bras.: Leviatã. São Paulo: Abril Cultural - col. “Os Pensadores", 1979], 1992.

HOFSTADTER, Douglas R. Gödel, Escher, Bach: an Eternal Golden Braid. Hassocks: The Harvester Press [trad. bras.: Gödel, Escher, Bach: um entrelaçamento de gênios brilhantes. Brasília: UnB/São Paulo: Imprensa Oficial, 2001], 1979.

HSIEH, Nien-hê. Incommensurable Values. In: ZALTA, N. (org.). The Stanford Encyclopedia of Philosophy (Spring 2016 Edition), 2016. Disponível em: $<$ https://plato.stanford.edu/archives/spr2016/entries/value-incommensurable/>. Acesso em: 05 maio 2019.

HUSSERL, Edmund. Die Krisis der europäischen Wissenschaften und die transzendentale Phänomenologie: Eine Einleitung in die phänomenologische 
Philosophie. STRÖKER, E. (Org.). 2. ed. Hamburg: Felix Meiner Verlag [originalmente in: Philosophia, v. I, Belgrado, 1936], 1982.

KANT, Immanuel. Kritik der reinen Vernunft [1781 $\left.{ }^{\mathrm{A}} / 1787^{\mathrm{B}}\right]$. WEISCHEDEL, W (Org.). 11. ed. Frankfurt am Main: Suhrkamp, 2 volumes, 1990.

KLATT, Mathias; MEISTER, Moritz. The Constitutional Structure of Proportionality. Oxford: Oxford University Press, 2012 (2012a).

KLATT, Mathias; MEISTER, Moritz. Verhältnismässigkeit als Universelles Verfassungsprinzip. Der Staat, v. 51, p. 159-188, 2012 (2012b).

LADEUR, Karl-Heinz. Der Staat gegen die Gesellschaft: Zur Verteidigung der Rationalität der "Privatrechtsgesellschaft". Tübingen: Mohr, 2007.

LADEUR, Karl-Heinz. Die transsubjektive Dimension der Grundrechte. In: VESTING, T.; KORIOTH, S.; AUGSBERG, I. Grundrechte als Phänomene kollektiver Ordnung. Tübingen: Mohr, p. 17-38, 2014.

LOCKE, John. Second Treatise of Government. MACPHERSON, C. B. (Org.). Indianapolis/Cambridge: Hackett Publishing Company [1 $1^{\underline{a}}$ ed. 1690] [trad. bras.: Segundo Tratado sobre o Governo Civil. São Paulo: Abril Cultural - col. “Os Pensadores", 1978], 1980.

LUHMANN, Niklas. Soziale Systeme: Grundriß einer allgemeinen Theorie. Frankfurt am Main: Suhrkamp, 1984.

LUHMANN, Niklas. Rechtssoziologie. 3. ed. Opladen: Westdeutscher Verlag [1. ed. Reinbek bei Hamburg: Rowohlt, 1972, 2 volumes] [trad. bras.: Sociologia do direito. Rio de Janeiro: Tempo Brasileiro, 2 volumes, 1983], 1987.

LUHMANN, Niklas. Die Wissenschaft der Gesellschaft. Frankfurt am Main: Suhrkamp, 1990. 
MÖLLERS, Christoph. Die Möglichkeit der Normen. Über eine Praxis jenseits von Moralität und Kausalität. Berlim: Suhrkamp, 2015.

MÜLLER, Friedrich. Die Positivität der Grundrechte: Fragen einer praktischen Grundrechtsdogmatik. 2. ed. Berlim: Duncker und Humblot, 1990.

MÜLLER, Friedrich. Strukturierende Rechtslehre. 2. ed. Berlim: Duncker und Humblot, 1994.

MÜLLER, Friedrich. Juristische Methodik. 6. ed. Berlim: Duncker und Humblot, 1995.

NEVES, Marcelo. Verfassung und Positivität des Rechts in der peripheren

Moderne: Eine theoretische Betrachtung und eine Interpretation des Falls Brasilien.

Berlim: Duncker \& Humblot, 1992.

NEVES, Marcelo. A constitucionalização simbólica: São Paulo: WMF Martins Fontes, 2007.

NEVES, Marcelo. Transconstitucionalismo. São Paulo: WMF Martins Fontes, 2009.

NEVES, Marcelo. Entre Hidra e Hércules: princípios e regras constitucionais como diferença paradoxal do sistema jurídico. São Paulo: WMF Martins Fontes [2. ed. 2014], 2013.

RAMOS, Guerreiro. A redução sociológica. 3. ed. Rio de Janeiro: Editora UFRJ, 1996.

REIMER, Philip. ... Und machet zu Jüngern alle Völker'? Von 'universellen Verfassungsprinzipien' und der Weltdimension der Prinzipientheorie der Grundrechte. Der Staat, v. 52, p. 27-57, 2013.

SIECKMANN, Jan-Reinard. El modelo de los principios del derecho. Bogotá: Universidad Externado de Colombia, 2006.

SILVA, V. A. Grundrechte und gesetzgeberische Spielräume. Baden-Baden: Nomos, 2002. 
SILVA, V. A. Interpretação constitucional e sincretismo metodológico. In: SILVA, V. A. (org.). Interpretação constitucional. São Paulo: Malheiros, p. 115-143, 2005.

SILVA, V. A. Prinzipientheorie, Abwägungskompetenz und Gewaltenteilung. In: Sieckmann, Jan-R. (org.). Die Prinzipientheorie der Grundrechte: Studien zur Grundrechtstheorie Robert Alexys. Baden-Baden: Nomos, p. 215-230, 2007.

SILVA, V. A. Comparing the Incommensurable: Constitutional Principles, Balancing and Rational Decision. Oxford Journal of Legal Studies, v. 31, p. 273-301, 2011.

SILVA, V. A. O Supremo Tribunal Federal precisa de Iolau: Resposta às objeções de Marcelo Neves ao sopesamento e à otimização. Revista de Direito da Universidade de Brasília, v. 2, n. 1, p. 96-118, 2016.

SIMON, Herbert. A Behavioral Model of Rational Choice. The Quarterly Journal of Economics, v. 69, n. 1, p. 99-118, 1955.

SIMON, Herbert. Rational Choice and the Structure of the Environment. Psychological Review, v. 63, n. 2, p. 129-38, 1956 (1956a).

SIMON, Herbert. A Comparison of Game Theory and Learning Theory.

Psychometrika: a Journal of Quantitative Psychology, v. 21, n. 3, p. 267-72, 1956 (1956b).

SUNSTEIN, Cass R. A Constitution of Many Minds: Why the Founding Document Doesn't Mean What It Meant Before. Princeton, NJ: Princeton University Press, 2009.

VON WRIGHT, Georg Henrik. Norm and Action: A Logical Enquiry. London: Routledge \& Kegan Paul, 1963.

WEBER, Max. Idealtypus, Handlungsstruktur und Verhaltensinterpretation (Auszüge). In: WINCKELMANN, J. (Org.). Methodologische Schriften. Frankfurt am Main: Fischer, p. 65-167, 1968.

WEBER, Max. Die 'Objektivität' sozialwissenschaftlicher und sozialpolitischer Erkenntnis. In: WINCKELMANN, J. (Org.) Gesammelte Aufsätze zur 
Wissenschaftslehre. 4 ed. Tübingen: Mohr, p. 146-214 [Originalmente in: Archiv für Sozialwissenschaft und Sozialpolitik, v. 19 (v. 1 na nova série), p. 22-87, 1904], 1973.

WEBER, Max. Wissenschaft als Beruf. 6. ed. Berlim: Duncker und Humblot [trad. bras.: A ciência como Vocação. In: Ciência e política: duas vocações. São Paulo: Cultrix, p. 17-64, 2011], 1975.

WEBER, Max. Wirtschaft und Gesellschaft: Grundriß der verstehenden Soziologie. WINCKELMANN, J. (Org.) 5. ed. Tübingen: Mohr [1. ed. 1922] [trad. bras.: Economia e sociedade: fundamentos da sociologia compreensiva. Brasília: UnB/São Paulo: Imprensa Oficial, 2 volumes, 2004], 1985.

ZUCCA, Lorenzo. Conflicts of Fundamental Rights as Constitutional Dilemmas. In: BREMS, E. (Org.). Conflicts between Fundamental Rights. Antwerp: Intersentia, p. 19-37, 2008. 